\title{
Parameterization of the light absorption properties of chromophoric dissolved organic matter in the Baltic Sea and Pomeranian lakes
}

\author{
Justyna Meler $^{1}$, Piotr Kowalczuk ${ }^{1}$, Mirosława Ostrowska ${ }^{1}$, Dariusz Ficek ${ }^{2}$, Monika Zabłocka ${ }^{1}$, and Agnieszka Zdun ${ }^{1}$ \\ ${ }^{1}$ Institute of Oceanology Polish Academy of Sciences, Powstańców Warszawy 55, 81-712 Sopot, Poland \\ ${ }^{2}$ Institute of Physics, Pomeranian University of Słupsk, Bohaterów Westerplatte 64, 76-200 Słupsk, Poland \\ Correspondence to: Justyna Meler (jmeler@iopan.pl)
}

Received: 16 May 2016 - Published in Ocean Sci. Discuss.: 23 May 2016

Revised: 1 August 2016 - Accepted: 2 August 2016 - Published: 26 August 2016

\begin{abstract}
This study presents three alternative models for estimating the absorption properties of chromophoric dissolved organic matter $a_{\mathrm{CDOM}}(\lambda)$. For this analysis we used a database containing 556 absorption spectra measured in 2006-2009 in different regions of the Baltic Sea (open and coastal waters, the Gulf of Gdańsk and the Pomeranian Bay), at river mouths, in the Szczecin Lagoon and also in three lakes in Pomerania (Poland) - Obłęskie, Łebsko and Chotkowskie. The variability range of the chromophoric dissolved organic matter (CDOM) absorption coefficient at $400 \mathrm{~nm}, a_{\mathrm{CDOM}}(400)$, lay within $0.15-8.85 \mathrm{~m}^{-1}$. The variability in $a_{\mathrm{CDOM}}(\lambda)$ was parameterized with respect to the variability over 3 orders of magnitude in the chlorophyll $a$ concentration Chl $a\left(0.7-119 \mathrm{mg} \mathrm{m}^{-3}\right)$. The chlorophyll $a$ concentration and $a_{\mathrm{CDOM}}(400)$ were correlated, and a statistically significant, nonlinear empirical relationship between these parameters was derived $\left(R^{2}=0.83\right)$. On the basis of the covariance between these parameters, we derived two empirical mathematical models that enabled us to design the CDOM absorption coefficient dynamics in natural waters and reconstruct the complete CDOM absorption spectrum in the UV and visible spectral domains. The input variable in the first model was the chlorophyll $a$ concentration, and in the second one it was $a_{\mathrm{CDOM}}(400)$. Both models were fitted to a power function, and a second-order polynomial function was used as the exponent. Regression coefficients for these formulas were determined for wavelengths from 240 to $700 \mathrm{~nm}$ at $5 \mathrm{~nm}$ intervals. Both approximations reflected the real shape of the absorption spectra with a low level of uncertainty. Comparison of these approximations with other models of light absorption by CDOM demonstrated that our parameterizations were superior (bias from -1.45 to $62 \%$,
\end{abstract}

RSME from 22 to $220 \%$ ) for estimating CDOM absorption in the optically complex waters of the Baltic Sea and Pomeranian lakes.

\section{Introduction}

All natural waters contain optically significant constituents that determine their inherent optical properties, i.e., the absorption coefficient, scattering coefficient and beam attenuation coefficient. The total absorption coefficient in the ultraviolet and visible spectral range of the electromagnetic radiation spectrum is almost entirely determined by four main groups of absorbents: water molecules, organic and inorganic suspended particulate matter (SPM), and chromophoric dissolved organic matter (CDOM). The quantitative and qualitative properties of these absorbents significantly affect the amount and spectral distribution of light in the aquatic environment. The absorption of pure water, as measured by Pope and Fry (1997), is almost constant in natural waters and can be omitted from the following analysis because it does not contribute to the variability in the total absorption coefficient. Changes in spectral values of pure seawater absorption are almost entirely determined by the concentration and composition of sea salt ions and dissolved gases; these substances effect the pure seawater absorption in the UV-A and UV-B spectral regions below $300 \mathrm{~nm}$ (Woźniak and Dera, 2007). Spectral properties (values and spectral shape) and the mutual proportions of light absorption coefficients of CDOM $\left(a_{\mathrm{CDOM}}(\lambda)\right)$, phytoplankton pigments $\left(a_{\mathrm{ph}}(\lambda)\right)$, organic detritus and mineral particles $\left(a_{\mathrm{NAP}}(\lambda)\right)$ determine the spectral shape and magnitude of the total absorption spectrum as well 
as affecting both the inherent and the apparent optical properties of natural waters (Woźniak and Dera, 2007).

Chromophoric dissolved organic matter $(\mathrm{CDOM})$ is the uncharacterized fraction of the dissolved organic matter pool consisting of a heterogeneous mixture of water-soluble organic compounds that have the ability to absorb light (Nelson and Siegel, 2002). The effect of CDOM absorption is mostly visible in the UV and blue spectral range of electromagnetic radiation, where the CDOM contribution to the total non-water absorption can be as much as $90 \%$, even in the clearest natural waters found in the South Pacific subtropical gyre south of Easter Island (Morel et al., 2007; Bricaud et al., 2010; Tedetti et al., 2010). The CDOM absorption band also overlaps the primary phytoplankton pigment absorption band in the blue part of the spectrum; this leads to significant errors in standard algorithms for retrievals of chlorophyll $a$, especially in coastal ocean and shelf waters and semi-enclosed seas (Darecki and Stramski, 2004; Siegel et al., 2005). Therefore, appropriate quantitative and qualitative descriptions of the optical properties of CDOM are crucial for the ocean color remote sensing of aquatic environments.

The CDOM absorption coefficient is a very reliable predictor of the dissolved organic carbon concentration in fresh and estuarine waters (Brezonik et al., 2015; Kutser et al., 2015; Toming et al., 2016), and therefore this optical parameter could be easily applied to various aspects of organic carbon biogeochemistry. Ocean color remote sensing offers new operational satellite missions based on medium ground resolution (of the order of $250 \mathrm{~m}$ ) sensors, like the European Earth Observation Copernicus program Sentinel3 Ocean and Land Colour Instrument (OLCI) mission, and the US Joint Polar Satellite System program Visible Infrared Imaging Radiometer Suite (VIIRS) sensors. These radiometers are particularly suitable for remote-sensing observations of inland water bodies and estuaries (Palmer et al., 2015; Kwiatkowska et al., 2016). The optical properties of CDOM, abundant in fresh and estuarine waters at high concentrations, shift the spectral maximum of the water transparency to solar radiation and water-leaving radiance towards the longer wavelengths (Darecki et al., 2003; Morel and Gentili, 2009). In extreme cases, in humic boreal lakes, CDOM reduces the water-leaving radiance intensity in the visible spectrum almost to zero (Ficek et al., 2011, 2012; Ylöstalo et al., 2014). To minimize this effect, the remote-sensing algorithm for retrieving bio-optical and biogeochemical variables in optically complex waters is based on spectral band combinations at longer wavelengths where CDOM absorption is low (e.g., Ficek et al., 2011). Therefore, models need to be developed that enable the complete CDOM absorption spectrum to be reconstructed. Detailed spectral information of CDOM absorption is required, for example, to calculate the spectral indices related to molecular weight, degree of photochemical transformation (Helms et al., 2008) or aromaticity (Weishaar et al., 2003).
CDOM also plays various ecological roles in aquatic environments: even small concentrations strongly absorb UV radiation, protecting organisms from its destructive action. Higher levels of CDOM absorption limit the amount of radiation available for photosynthesis, consequently reducing the primary production of organic matter in that water (Gorrniak, 1996; Wetzel, 2001). CDOM plays an important part in the various biological processes taking place in water bodies: it can affect the species composition, number and size of plankton organisms (Arrigo and Brown, 1996; Campanelli et al., 2009) and in oligotrophic lakes can promote the growth of bacterioplankton (Moran and Hodson, 1994). Several authors have pointed out that CDOM is a potential source of reactive oxygen forms in aquatic ecosystems, which has a considerable influence on a variety of biological processes (Whitehead and de Mora, 2000; Kieber et al., 2003).

CDOM absorption decreases exponentially towards longer wavelengths and can be described by the following exponential function (Jerlov, 1976; Bricaud et al., 1981; Kirk, 1994):

$a_{\mathrm{CDOM}}(\lambda)=a_{\mathrm{CDOM}}\left(\lambda_{0}\right) e^{-S\left(\lambda_{0}-\lambda\right)}$,

where $a_{\mathrm{CDOM}}(\lambda)$ is the light absorption coefficient for a given wavelength $\lambda, \lambda_{0}$ is the reference wavelength and $S$ is the slope of the spectrum within a given wavelength interval.

CDOM accumulates in surface Baltic Sea waters as a combined effect of a very large inflow of freshwater from rivers, the limited exchange of waters with the North Sea and the very high productivity in that sea (Kowalczuk et al., 2006). Systematic studies over the last 2 decades on the optical properties of Baltic Sea waters and its adjoining freshwater systems, i.e., coastal lagoons and Pomeranian lakes, have yielded evidence that CDOM is the principal absorbent of solar radiation and the main factor governing their optical properties (Kowalczuk, 1999; Kowalczuk et al., 2005a, 2006, 2010; Ficek et al., 2012; Ficek, 2013).

We performed analyses using a combined data set of optical properties of marine and lacustrine water samples, treating the data as a single, pooled set. The optical properties of lacustrine waters resembled the Baltic Sea waters, despite the differences in the trophic status of these water bodies. In accordance with Choiński (2007), the lake waters were divided into ultra-oligotrophic, oligotrophic, mesotrophic, eutrophic, hypereutrophic and dystrophic. The trophicity was determined from the concentration of chlorophyll $a$, the water transparency (measured using a Secchi disk) and the concentration of nutrients, e.g., nitrogen and phosphorus (Carlson, 1977; Kratzer and Brezonik, 1981). The ranges of concentrations of chlorophyll and trophicity-defining nutrients were wider in lakes than in seawater. In our modeling approach we assumed that lakes could be treated as a natural extension of coastal, lagoon and river mouth waters.

The main objective of the present work was to derive three alternative parameterization scenarios of the relationships between the CDOM absorption coefficient in Baltic 
and Pomeranian lake waters and physical or biogeochemical variables. The motivation for developing these models was to estimate the complete spectrum of CDOM light absorption coefficients by using different input parameters: (i) known chlorophyll $a$ concentrations in the first scenario, (ii) known values of the CDOM absorption coefficient at $400 \mathrm{~nm}\left(a_{\mathrm{CDOM}}(400)\right)$ in the second scenario, (iii) and known values of $a_{\mathrm{CDOM}}(400)$ and known nonlinear relationships between the CDOM absorption coefficient and the spectral slope coefficient $S$ in the third scenario. These models can be used to improve the accuracy of ocean color remotesensing algorithms for retrieving environmental variables in the Baltic Sea, adjacent river mouths, lagoons and freshwater lakes.

\section{Material and methods}

\subsection{Sampling area}

Water samples for determining optically significant water constituent concentrations were collected from August 2006 to November 2009 in the southern Baltic and in three lakes in the Pomeranian Lake District (Poland) during the longterm observation program of inherent and apparent optical properties for calibrating and validating ocean color satellite imagery products, run by the Institute of Oceanology, Polish Academy of Sciences, Sopot, Poland (IOPAN). The locations of the 116 measuring stations where empirical data were gathered (a total of 413 data sets) during 16 cruises of R/V Oceania on the Baltic are shown in Fig. 1, and the cruise details are given in Table 1. The research cruises were organized so as to capture the dynamics of natural seasonal variability occurring in temperate waters: (i) at the end of winter, before the onset of the spring phytoplankton bloom, when wind-driven mixing, the vertical convective thermohaline circulation, reduced biological activity and reduced riverine outflow all result in clearer surface waters; (ii) in spring, when the spring phytoplankton bloom coincides with the maximum freshwater runoff from the Baltic Sea drainage basin; (iii) at the end of summer, when secondary phytoplankton blooms peak and the thermal stratification of waters reaches its maximum extent. The geographical coverage of the samples included the Gulf of Gdansk, the Pomeranian Bay, the Szczecin Lagoon, Polish coastal waters and the open sea (the Baltic proper). The coastal sites in the Gulf of Gdańsk and the Pomeranian Bay are under the direct influence of two major river systems, the Vistula and the Odra, respectively, which drain the majority of Poland. Additionally, samples were collected twice a month at the sampling station on the Sopot pier (Gulf of Gdańsk), from which 66 sets of data were obtained. Field observations were also carried out from April 2006 to November 2009 at monthly intervals (except for the months when the lake surfaces were covered with ice) at three Pomeranian lakes (Łebsko, Chotkowskie

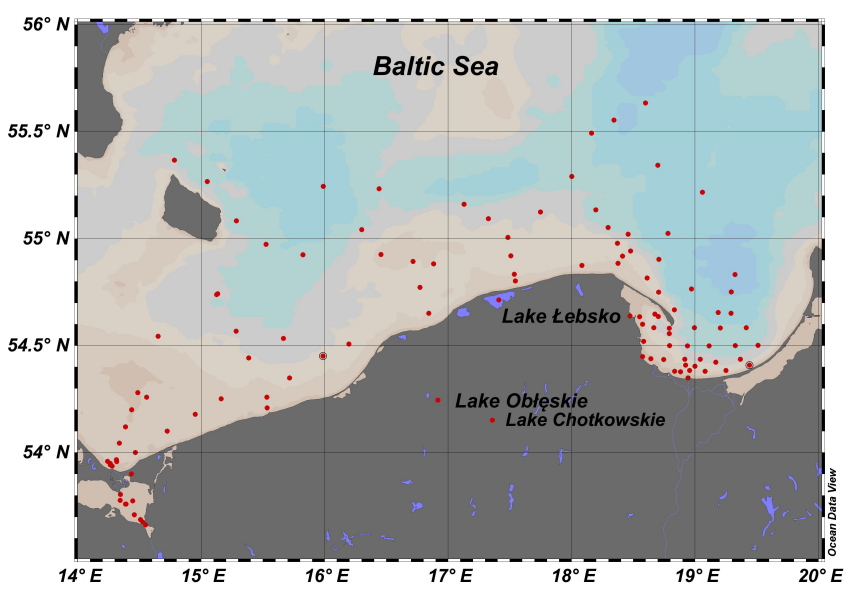

Figure 1. Positions of the measurement stations in 2006-2009.

and Obłęskie), from which 77 data sets were obtained. These lakes are enclosed water bodies with only small rivers flowing in and out of them. Lake Łebsko is a special case, however; it is a coastal lake, connected directly to the sea by a short channel. Part of the land around Lake Łebsko immediately adjacent to the channel can, on occasion, be inundated when large backflows of seawater enter the lake. The lake's water level can then rise by $50-60 \mathrm{~cm}$ (Chlost and Cieśliński, 2005). Such a situation obviously affects the composition and properties of the lacustrine water. Similar effects, resulting from the great variability of water properties, can be expected at the points where rivers flow into lakes. The lacustrine water in these areas is thus modified by the river water.

\subsection{Sample processing}

Discrete samples of water were taken from the surface layer of the southern Baltic and the three Pomeranian lakes with a Niskin bottle. The samples for spectroscopic measurements of CDOM light absorption were filtered twice: once through acid-washed Whatman glass-fiber filters (GF/F, nominal pore size $0.7 \mu \mathrm{m}$ ) and then through acid-washed Sartorius $0.2 \mu \mathrm{m}$ pore cellulose membrane filters to remove fine particles. Spectrophotometric scans of CDOM absorption spectra were done with a Unicam UV4-100 double-beam spectrophotometer in the 240-700 nm spectral range; these instruments were installed in the land laboratory and on board the research ship. The cuvette path length was $5 \mathrm{~cm}$ and MilliQ water was used as the reference for all measurements. The absorption coefficient $a_{\mathrm{CDOM}}(\lambda)$ was calculated using the following equation:

$a_{\mathrm{CDOM}}(\lambda)=2.303 \cdot A(\lambda) / L$,

where $A(\lambda)$ is the optical density and $L$ is the optical path length in meters; the factor 2.303 is the natural logarithm of 10. 
Table 1. Dates, numbers of samples collected and parameters measured during cruises and field experiments carried out for this study.

\begin{tabular}{|c|c|c|c|}
\hline Dates of cruises & $\begin{array}{r}\text { Number of } \\
\text { samples }\end{array}$ & Parameters measured & Region \\
\hline 24-31 Aug 2006 & 20 & $a_{\mathrm{CDOM}}(\lambda)$, Chl $a, \mathrm{CTD}$ & southern Baltic proper, Gulf of Gdańsk \\
\hline 24-29 Sep 2006 & 12 & $a_{\mathrm{CDOM}}(\lambda)$, Chl $a, \mathrm{CTD}$ & southern Baltic proper, Gulf of Gdańsk \\
\hline $18-28$ Oct 2006 & 30 & $a_{\mathrm{CDOM}}(\lambda)$, Chl $a, \mathrm{CTD}$ & $\begin{array}{l}\text { southern Baltic proper, Gulf of Gdańsk, } \\
\text { Pomeranian Bay }\end{array}$ \\
\hline 21-31 Mar 2007 & 36 & $a_{\mathrm{CDOM}}(\lambda)$, Chl $a, \mathrm{CTD}$ & $\begin{array}{l}\text { southern Baltic proper, Gulf of Gdańsk, } \\
\text { Pomeranian Bay, Szczecin Lagoon }\end{array}$ \\
\hline 21-31 May 2007 & 38 & $a_{\mathrm{CDOM}}(\lambda)$, Chl $a, \mathrm{CTD}$ & southern Baltic proper, Gulf of Gdańsk \\
\hline 20-28 Oct 2007 & 26 & $a_{\mathrm{CDOM}}(\lambda)$, Chl $a, \mathrm{CTD}$ & southern Baltic proper, Gulf of Gdańsk \\
\hline 1-11 Mar 2008 & 29 & $a_{\mathrm{CDOM}}(\lambda)$, Chl $a, \mathrm{CTD}$ & $\begin{array}{l}\text { southern Baltic proper, Gulf of Gdańsk, } \\
\text { Pomeranian Bay }\end{array}$ \\
\hline 11-18 Apr 2008 & 22 & $a_{\mathrm{CDOM}}(\lambda)$, Chl $a, \mathrm{CTD}$ & southern Baltic proper, Gulf of Gdańsk \\
\hline 6-14 May 2008 & 23 & $a_{\mathrm{CDOM}}(\lambda)$, Chl $a, \mathrm{CTD}$ & southern Baltic proper, Gulf of Gdańsk \\
\hline 1-9 Sep 2008 & 26 & $a_{\mathrm{CDOM}}(\lambda)$, Chl $a, \mathrm{CTD}$ & $\begin{array}{l}\text { southern Baltic proper, Gulf of Gdańsk, } \\
\text { Pomeranian Bay, Szczecin Lagoon }\end{array}$ \\
\hline 25-29 Nov 2008 & 18 & $a_{\mathrm{CDOM}}(\lambda)$, Chl $a, \mathrm{CTD}$ & Gulf of Gdańsk \\
\hline 4-12 Mar 2009 & 14 & $a_{\mathrm{CDOM}}(\lambda)$, Chl $a, \mathrm{CTD}$ & Gulf of Gdańsk, Gotland Basin \\
\hline 15-21 Apr 2009 & 29 & $a_{\mathrm{CDOM}}(\lambda)$, Chl $a, \mathrm{CTD}$ & southern Baltic proper, Gulf of Gdańsk \\
\hline 20-28 May 2009 & 34 & $a_{\mathrm{CDOM}}(\lambda)$, Chl $a, \mathrm{CTD}$ & $\begin{array}{l}\text { southern Baltic proper, Gulf of Gdańsk, } \\
\text { Pomeranian Bay, Szczecin Lagoon }\end{array}$ \\
\hline 7-16 Sep 2009 & 35 & $a_{\mathrm{CDOM}}(\lambda)$, Chl $a, \mathrm{CTD}$ & southern Baltic proper, Gulf of Gdańsk \\
\hline $6-10$ Oct 2009 & 21 & $a_{\mathrm{CDOM}}(\lambda)$, Chl $a, \mathrm{CTD}$ & southern Baltic proper, Gulf of Gdańsk \\
\hline Dec 2006-Sep 2009 & 66 & $a_{\mathrm{CDOM}}(\lambda)$, Chl $a$ & Sopot pier \\
\hline Apr-Dec 2007 & 10 & $a_{\mathrm{CDOM}}(\lambda)$, Chl $a$ & Lake Łebsko \\
\hline Apr-Sep 2008 & 8 & $a_{\mathrm{CDOM}}(\lambda)$, Chl $a$ & Lake Łebsko \\
\hline Jun-Oct 2009 & 9 & $a_{\mathrm{CDOM}}(\lambda)$, Chl $a$ & Lake Łebsko \\
\hline Mar-Dec 2007 & 10 & $a_{\mathrm{CDOM}}(\lambda)$, Chl $a$ & Lake Chotkowskie \\
\hline Feb-Sep 2008 & 8 & $a_{\mathrm{CDOM}}(\lambda)$, Chl $a$ & Lake Chotkowskie \\
\hline Apr-Nov 2009 & 8 & $a_{\mathrm{CDOM}}(\lambda)$, Chl $a$ & Lake Chotkowskie \\
\hline Mar-Dec 2007 & 9 & $a_{\mathrm{CDOM}}(\lambda)$, Chl $a$ & Lake Obłęskie \\
\hline Feb-Sep 2008 & 8 & $a_{\mathrm{CDOM}}(\lambda)$, Chl $a$ & Lake Obłęskie \\
\hline May-Nov 2009 & 7 & $a_{\mathrm{CDOM}}(\lambda)$, Chl $a$ & Lake Obłęskie \\
\hline All data & 556 & & \\
\hline
\end{tabular}

A nonlinear least squares fitting method using the Trustregion algorithm implemented in Matlab R2009 was applied (Stedmon et al., 2000; Kowalczuk et al., 2006, 2015) to calculate the CDOM absorption spectrum slope coefficient $S$ in the $300-600 \mathrm{~nm}$ spectral range using the equation

$a_{\mathrm{CDOM}}(\lambda)=a_{\mathrm{CDOM}}\left(\lambda_{0}\right) e^{-S\left(\lambda_{0}-\lambda\right)}+K$,

where $\lambda_{0}$ is $350 \mathrm{~nm}$ and $K$ is a background constant that allows for any baseline shift caused by residual scattering due to fine particle fractions, micro-air bubbles or colloidal material present in the sample, refractive index differences between the sample and the reference, or attenuation not due to CDOM. The parameters $a_{\mathrm{CDOM}}(350), S$ and $K$ were estimated simultaneously by nonlinear regression using Eq. (3) (Kowalczuk et al., 2006).

The chlorophyll $a$ concentration was determined by pigment extraction. The pigments contained in the suspended particles were collected by passing the water samples through $47 \mathrm{~mm}$ Whatman glass-fiber filters (GF/F) under a low vacuum and extracted in $96 \%$ ethanol at room temperature for $24 \mathrm{~h}$ (Wintermans and De Mots, 1965; Marker et al., 1980). The chlorophyll $a$ concentration, Chl $a$, was determined spectrophotometrically with a Unicam UV4100 spectrophotometer. In this method the optical density (absorbance) of the pigment extract in ethanol at $665 \mathrm{~nm}$ was corrected for the background signal in the near infrared $(750 \mathrm{~nm}): \Delta \mathrm{OD}=\mathrm{OD}(665 \mathrm{~nm})-\mathrm{OD}(750 \mathrm{~nm})$; the absorbance was converted to the chlorophyll $a$ concentration using an equation involving the volumes of filtered water $\left(V_{\mathrm{w}}\right)\left(\mathrm{dm}^{3}\right)$ and ethanol extract $\left(V_{\mathrm{EtOH}}\right)\left(\mathrm{cm}^{3}\right)$, a $2 \mathrm{~cm} \mathrm{cu}-$ vette path length $(l)$, and the specific absorption coefficient of chlorophyll $a$ in $96 \%$ ethanol $\left(\mathrm{dm}^{3}\left(\mathrm{~g} \mathrm{~cm}^{-1}\right)\right.$ (for $\left.665 \mathrm{~nm}\right)$ (Strickland and Parsons, 1972; Stramska et al., 2003):

Chl $a=\left(10^{3} \cdot \Delta \mathrm{OD} \cdot V_{\mathrm{EtOH}}\right) /\left(83 \cdot V_{\mathrm{w}} \cdot l\right)^{-1}$. 
During the fieldwork, temperature and salinity profiles were measured with a SeaBird SB36 conductivity-temperaturedepth (CTD) probe to provide the background physical conditions to sampling.

The data obtained were analyzed using a statistical package and data visualization software (SigmaPlot 8.1). As the dynamic range of variability of the optical parameters exceeded 3 orders of magnitude, logarithmic transformation was applied for a better presentation of their dynamic changes and to statistically analyze the dataset accordingly. The following arithmetic and logarithmic statistical metrics were used to assess the uncertainty of the empirical relationships and models ( $X_{i, \mathrm{M}}$ - measured values; $X_{i, \mathrm{C}}-$ estimated values (the subscript $M$ stands for "measured"; $C$ stands for "calculated")):

- relative mean error (systematic):

$$
\langle\varepsilon\rangle=N^{-1} \sum_{i} \varepsilon_{i}\left(\text { where } \varepsilon_{i}=\left(X_{i, \mathrm{C}}-X_{i, \mathrm{M}}\right) / X_{i, \mathrm{M}}\right)
$$

- standard deviation (statistical error) of $\varepsilon$ (RMSE - root mean square error):

$$
\sigma_{\varepsilon}=\sqrt{\frac{1}{N}\left(\sum\left(\varepsilon_{i}-<\varepsilon>\right)^{2}\right)}
$$

- mean logarithmic error:

$$
\langle\varepsilon\rangle_{g}=10^{\left[\left\langle\log \left(X_{i, \mathrm{C}} / X_{i, \mathrm{M}}\right)\right\rangle\right]}-1
$$

- standard error factor:

$$
x=10^{\sigma_{\log }}
$$

- statistical logarithmic errors:

$$
\begin{gathered}
\sigma_{+}=x-1 \quad \sigma_{-}=\frac{1}{x}-1 \\
-\left\langle\log \left(X_{i, \mathrm{C}} / X_{i, \mathrm{M}}\right)\right\rangle-\text { mean of } \log \left(X_{i, \mathrm{C}} / X_{i, \mathrm{M}}\right) \\
-\sigma_{\log }-\text { standard deviation of the set } \log \left(X_{i, \mathrm{C}} / X_{i, \mathrm{M}}\right)
\end{gathered}
$$

The linear metrics are represented by the relative mean error, and the standard deviation was used to measure the dispersion of results and assess the model's uncertainty. The relative mean error (Eq. 5a) is the average of all relative deviations between measured and calculated values and quantifies the systematic error. The standard deviation (Eq. 5b) is the dispersion around the average error due to random errors and quantifies the statistical error. Logarithmic metrics are used to better describe the uncertainty in the data set varying over several orders of magnitude. The standard error factor describes how many times the error deviates from the average value.

\section{Results}

\subsection{Variability of the parameters and empirical relationship between CDOM absorption and spectral slope coefficient}

Table 2 lists the variability range and average values of selected optical parameters measured in the study area and used for formulating the empirical model: the light absorption coefficients by CDOM at two wavelengths (375 and $400 \mathrm{~nm} ; a_{\mathrm{CDOM}}(375)$ and $a_{\mathrm{CDOM}}(400)$, the spectral slope $S$ and chlorophyll $a$ concentrations Chl $a$. The variability ranges of $a_{\mathrm{CDOM}}(375), a_{\mathrm{CDOM}}(400)$ and $\mathrm{Chl} a$ reached a minimum in seawater. The minimum CDOM absorption coefficients in lacustrine waters were almost 1 order of magnitude higher than in seawater, indicating a significant accumulation of CDOM in freshwater. The maximum values of $a_{\mathrm{CDOM}}(375), a_{\mathrm{CDOM}}(400)$ and Chl $a$ were recorded in freshwater: these values were approximately twice as high as those of the respective parameters in seawater. Consequently, the average CDOM absorption coefficients $\left(a_{\mathrm{CDOM}}(375)\right.$, $\left.a_{\mathrm{CDOM}}(400)\right)$ and chlorophyll $a$ concentrations were higher in fresh- than in seawater. The trend was reversed in the case of the CDOM absorption spectrum slope coefficient $S$ and its variability range: both the maximum and minimum spectral slopes were lower in the lakes than in the seawater. The average spectral slope coefficient was higher in seawater than in lake waters. These two data sets, measured in the Baltic Sea and Pomeranian lakes, were statistically significantly different, as indicated by the results of a simple analysis of variance: $p=3.4 \times 10^{-38}$. However, their variability ranges were such, that the data from the two different aquatic environments overlapped, creating a coherent data set that could be analyzed jointly. Our principle assumption when deriving the CDOM absorption model was that the optical properties of lacustrine waters could be treated as if they were an extension of estuarine and seawater.

The spectral slope coefficient was inversely and nonlinearly related to the CDOM absorption coefficient. The highly absorbing samples were spectrally flatter (characterized by a lower $S$ value). Hyperbolic (Stedmon and Markager, 2001; 
Table 2. Range of variability of the spectral slope $S_{300-600}$, coefficients of light absorption by CDOM for wavelengths $\lambda=375$ and $400 \mathrm{~nm}\left(a_{\mathrm{CDOM}}(375)\right.$ and $\left.a_{\mathrm{CDOM}}(400)\right)$, and concentrations of chlorophyll $a(\mathrm{Chl} a)$, calculated for the empirical data.

\begin{tabular}{lccc}
\hline $\begin{array}{l}\text { Study } \\
\text { area }\end{array}$ & $\begin{array}{c}\text { Range of } \\
\text { variability }\end{array}$ & $\begin{array}{c}\text { Mean } \\
\text { value }\end{array}$ & SD \\
\hline \multicolumn{4}{c}{$S_{300-600}\left(\mathrm{~nm}^{-1}\right)$} \\
\hline Baltic & $0.014-0.03$ & 0.022 & 0.0021 \\
lakes & $0.007-0.02$ & 0.017 & 0.0030 \\
all & $0.007-0.03$ & 0.021 & 0.0022 \\
\hline \multicolumn{4}{c}{$a_{\mathrm{CDOM}}(375)\left(\mathrm{m}^{-1}\right)$} \\
\hline Baltic & $0.41-7.92$ & 1.61 & 1.17 \\
lakes & $2.11-14.16$ & 7.11 & 3.36 \\
all & $0.41-14.16$ & 2.06 & 2.17 \\
\hline \multicolumn{4}{c}{$a_{\mathrm{CDOM}}(400)\left(\mathrm{m}^{-1}\right)$} \\
\hline Baltic & $0.15-4.79$ & 0.997 & 0.73 \\
lakes & $1.28-8.85$ & 4.47 & 2.07 \\
all & $0.15-8.85$ & 1.35 & 1.41 \\
\hline \multicolumn{4}{c}{ Chl $a\left(\mathrm{mg} \mathrm{m}^{-3}\right)$} \\
\hline Baltic & $0.72-76.94$ & 8.77 & 11.61 \\
lakes & $1.48-118.97$ & 39.11 & 34.15 \\
all & $0.72-118.97$ & 13.09 & 19.78 \\
\hline
\end{tabular}

Kowalczuk et al., 2006) and logarithmic (Kowalczuk et al., 2005b) functional types were used to model this relationship. For consistency with Kowalczuk (2001), we used the loglinear fit to describe the relationship between $a_{\mathrm{CDOM}}(400)$ and $S$. The distribution of the spectral slope as a function of the CDOM absorption coefficient in the Baltic Sea (black dots) and Pomeranian lakes (green dots) is shown in Fig. 2a. The black line represents the log-linear dependence (Eq. 9) obtained by Kowalczuk (2001), overlaid on our data set:

$S=\log \left[1.038 a_{\mathrm{CDOM}}(400)^{-0.022}\right]$.

The old relationship works satisfactorily for part of the Baltic Sea data set $\left(R^{2}=0.76\right)$ but does not cover a large group of CDOM absorption coefficients $>5 \mathrm{~m}^{-1}$. The values of $a_{\mathrm{CDOM}}(400)>5 \mathrm{~m}^{-1}$ were measured in the lakes and estuarine waters, as well as in the Szczecin Lagoon and where the waters of the Vistula and Odra flow into the southern Baltic. We derived a new formula to determine the $a_{\mathrm{CDOM}}(400)-S$ relationship that covered the whole range of $a_{\mathrm{CDOM}}(400)$ recorded in both Baltic Sea and Pomeranian lake waters. The new formula is shown in Fig. 2a as a red curve and is described by Eq. (10):

$S=0.0213-0.003 \ln \left[a_{\mathrm{CDOM}}(400)\right]$.

The new $a_{\mathrm{CDOM}}(400)-S$ relationship is much better constrained and explains much more variance $\left(R^{2}=0.79\right)$ with
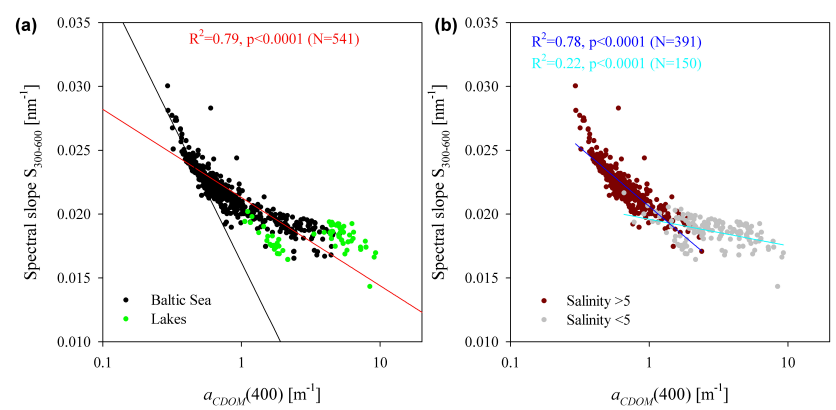

Figure 2. Relationship between the spectral slope $S_{300-600}$ and the coefficient of light absorption by CDOM for a wavelength of $400 \mathrm{~nm}, a_{\mathrm{CDOM}}(400)$, in the semi-log scale: (a) in the Baltic (black dots) and lakes (green dots) - the black curve is the approximation obtained by Kowalczuk (2001) and the red line represents the approximation given by Eq. (10); (b) for samples with salinity $>5$ (most of the seawater samples) and with salinity $<5$ (samples from lakes, river mouths, the Szczecin Lagoon) - the blue line represents the approximation given by Eq. (11) and the cyan line the approximation given by Eq. (12).

less uncertainty $(\mathrm{RMSE}=0.1 \%)$ compared to the one given by Kowalczuk (2001).

Detailed analysis of the spectral slope distribution as a function of $a_{\mathrm{CDOM}}(400)$ indicated that the data set could be divided into two subsets with respect to salinity: samples characterized by salinity $>5$ (mostly Baltic Sea water samples) and those with salinity $<5$, which include waters from river mouths, lakes and the Szczecin Lagoon. The relationship between $a_{\mathrm{CDOM}}(400)$ and $S$ derived for the respective data subsets is presented in Fig. $2 \mathrm{~b}$ and the functional formulas are given by Eqs. (11) (salinity $>5$ ) and 12 (salinity $<5$ ):

$S=0.0206-0.004 \ln \left[a_{\mathrm{CDOM}}(400)\right]$,

$S=0.0196-0.0009 \ln \left[a_{\mathrm{CDOM}}(400)\right]$.

The suggested approximations of the $a_{\mathrm{CDOM}}(400)-S$ relationships in the two salinity ranges have a lower explained variance $\left(R^{2}=0.78\right.$ for Eq. 11 and $R^{2}=0.22$ for Eq. 12 ). In both cases, the estimation uncertainties $-\mathrm{RSME}=0.08 \%$ for Eq. (11) and RSME $=0.09 \%$ for Eq. (12) - were lower than the approximation given by Eq. (10).

\subsection{A model for approximating the CDOM light absorption spectrum from the empirical dependence on the chlorophyll $a$ concentration}

The principle bio-optical assumption regarding interdependences among optically significant water constituents in the world ocean was formulated by Morel and Prieur (1977), who introduced the concept of Case 1 waters, where the variability of those constituents was to a considerable extent correlated with the variability in the phytoplankton biomass expressed as chlorophyll $a$ concentration. Case 1 waters were mostly open oceanic waters and upwelling regions along 
western continental margins. The sea areas where this assumption was not fulfilled were treated as Case 2 waters: mostly semi-enclosed and shelf seas and coastal oceans, where there were sources of riverine waters. It was assumed that changes in the magnitude of optically significant water constituents in Case 2 waters were independent. This concept was critically reassessed by Siegel et al. (2005), who reanalyzed the global ocean color imagery data set. They demonstrated that, although the bio-optical assumption was still valid in the open ocean, there were significant dependences between chlorophyll $a$ and other optically significant water constituents on regional scales along oceanic continental margins. Even though CDOM was not thought to be correlated with chlorophyll $a$ concentrations in Case 2 waters, there were examples showing that such a relationship was possible (Ferrari and Tassan, 1992; Vodacek et al., 1997). In Baltic waters such analyses were carried out by Kowalczuk and Kaczmarek (1996) and Kowalczuk (1999). These authors demonstrated that the concentration of chlorophyll $a$ and the CDOM absorption coefficient were correlated. The positive correlation between light absorption by CDOM and chlorophyll $a$ concentration has been confirmed with new data from both sea and freshwater. The clearly increasing trend of the CDOM absorption level with phytoplankton biomass is shown in Fig. 3. The dependence between $a_{\mathrm{CDOM}}(400)$ and Chl $a$ obtained by Kowalczuk (2001) has been overlaid on the new, updated empirical data set in Fig. 3. It is evident that the $a_{\mathrm{CDOM}}(400)-\mathrm{Chl} a$ relationship reported by Kowalczuk is applicable to only some of the Baltic Sea data, in the chlorophyll $a$ concentration range $0.8<\mathrm{Chl} a<10 \mathrm{mg} \mathrm{m}^{-3}$. The previous power function relationship did not reproduce correctly the $a_{\mathrm{CDOM}}(400)$ values for high chlorophyll $a$ concentrations, and CDOM absorption data measured in river mouths and lakes lay above the model curve. We propose a new, statistically significant relationship between $a_{\mathrm{CDOM}}(400)$ and $\mathrm{Chl} a$ that is described by a second-degree polynomial $\left(R^{2}=0.83\right.$, RMSE $=28 \%$, $n=541, p<0.0001$ ).

The same function has been applied to reconstruct the complete CDOM absorption spectrum in the spectral range from 245 to $700 \mathrm{~nm}$ with $5 \mathrm{~nm}$ resolution (Eq. 13):

$a_{\mathrm{CDOM}}(\lambda)=10^{\left(A(\lambda)(\log \mathrm{Chl} a)^{2}+B(\lambda) \log \mathrm{Chl} a+D(\lambda)\right)}$,

where $A(\lambda)\left(\mathrm{m}^{5} \mathrm{mg}^{-2}\right), B(\lambda)\left(\mathrm{m}^{2} \mathrm{mg}^{-1}\right)$ and $D(\lambda)\left(\mathrm{m}^{-1}\right)$ are the regression coefficients.

The spectral distribution of the regression coefficients and determination coefficient are presented in Fig. 4 and their values are included in Table A1 in Appendix A. Both regression coefficients $A(\lambda)$ and $B(\lambda)$ exhibited a relatively small spectral variation in the UV and part of the visible spectral range. The biggest changes in regression coefficient spectra were noted above $580 \mathrm{~nm}$, where a significant increase in $A(\lambda)$ was to a large extent compensated for by a decrease in $B(\lambda)$. The spectral distribution of regression co-

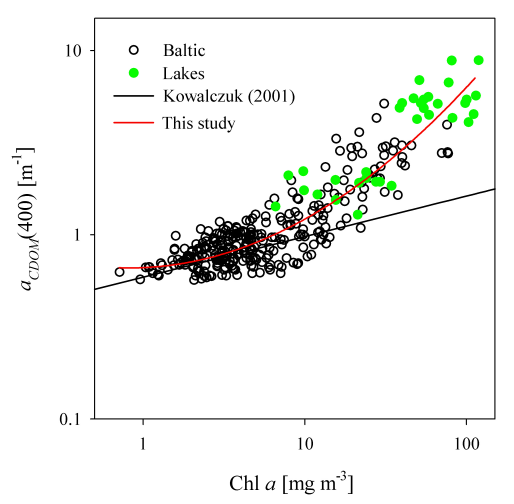

Figure 3. Dependence between coefficients of light absorption by CDOM $a_{\mathrm{CDOM}}(400)$ and chlorophyll $a$ concentration. The black line shows the approximation obtained by Kowalczuk (2001) and the red line shows the second-degree polynomial approximation on the $\log -\log$ scale.

efficient $A$ indicates the potential influence of phytoplankton pigment absorption on the CDOM absorption spectrum as its maximum, situated around $675 \mathrm{~nm}$, overlaps the longwave maximum of the chlorophyll $a$ absorption spectrum. This effect is apparent only at longer wavelengths because the principal chlorophyll $a$ maximum at $440 \mathrm{~nm}$ is masked by CDOM absorption, especially in very turbid estuarine water and freshwater, where the highest values of CDOM absorption were recorded. The free-term $D(\lambda)$ spectrum, decreasing monotonically with increased wavelength, resembles that of the log-transformed CDOM absorption coefficient spectrum corresponding to the average CDOM absorption spectrum at a chlorophyll $a$ concentration of $1 \mathrm{mg} \mathrm{m}^{-3}$, as shown in Fig. 4c. The spectral distribution of the determination coefficient $R^{2}$ (Fig. 4d) shows that the model based on the dependence between the CDOM absorption coefficient and the chlorophyll $a$ concentration explained more than $80 \%$ of the variability in $a_{\mathrm{CDOM}}(\lambda)$ in the UV and VIS and that this variability was governed by phytoplankton biomass production. The model's performance deteriorated at wavelengths longer than $550 \mathrm{~nm}$.

The results of the model uncertainty analysis for selected wavelengths are summarized in Table 3 and illustrated in Fig. 5. Comparison between estimated and measured $a_{\mathrm{CDOM}}(\lambda)$ values at selected wavelengths $(260,350$, $440,500,550,600 \mathrm{~nm}$ ) from the $240-700 \mathrm{~nm}$ range are shown in the first six upper panels of Fig. 5a-f. Histograms of the ratios of estimated to measured values at the same wavelengths are presented in the lower six panels of Fig. $5 \mathrm{~g}-$ 1. The deterioration of model performance with increasing wavelength is evident. The overall uncertainty expressed by arithmetic and logarithmic statistics was satisfactory up to $500 \mathrm{~nm}$, but then both systematic and statistical estimation errors increased rapidly at longer wavelengths. The arithmetic systematic error increased from $1.47 \%$ at $260 \mathrm{~nm}$ to $19.54 \%$ 

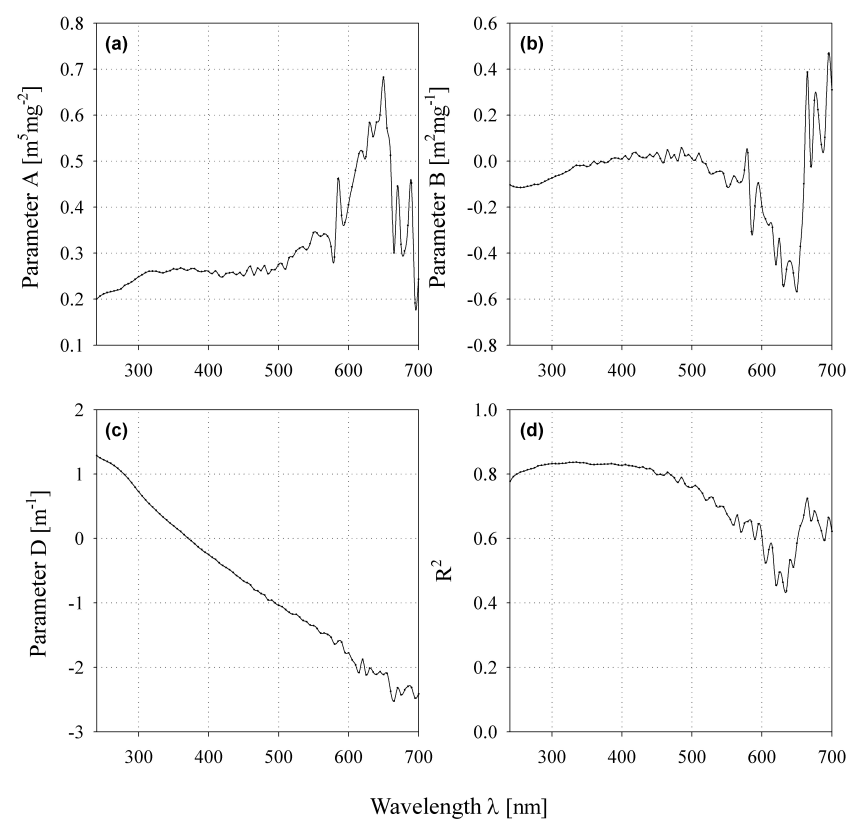

Figure 4. Spectral dependence of the model (expressed by Eq. 13) regression coefficients $(\mathbf{a}, \mathbf{b})$, free term $(\mathbf{c})$ and determination coefficient (d).

at $600 \mathrm{~nm}$, and the arithmetic statistical error increased from $17.03 \%$ at $260 \mathrm{~nm}$ to $79.13 \%$ at 600 . Logarithmic uncertainty metrics indicated that the standard error factor estimated for the entire spectral range from 240 to $700 \mathrm{~nm}$ of light absorption coefficients varied from 1.19 to 2.66 . This meant that the statistical logarithmic error varied from -62 to $+165 \%$. The logarithmic systematic errors throughout the 240-700 $\mathrm{nm}$ range did not exceed $3 \%$.

\subsection{An empirical model for approximating the CDOM light absorption spectrum based on the empirical dependence on the CDOM absorption coefficient at $400 \mathrm{~nm}, a_{\mathrm{CDOM}}(400)$}

The exponential model for CDOM absorption requires information on two input parameters: the magnitude of CDOM absorption at the reference wavelength and the spectral slope. However, the monotonicity of the CDOM absorption spectrum ensures a high level of interdependence between absorption coefficients across the spectral range in question, so that detailed information on the spectral slope can be omitted. The second model that we have developed is based on the dependence of light absorption by CDOM at any given wavelength and the CDOM absorption coefficient at a wavelength of $400 \mathrm{~nm}$. Many authors treat this wavelength as a reference for CDOM absorption using the exponential Eq. (1) (e.g., Kowalczuk et al., 2005a; Woźniak and Dera, 2007). It was also recommended by Sathyendranath et al. (1989) to distinguish between absorption by dissolved organic matter and that caused by phytoplankton. In optically complex waters (the Baltic Sea and the lakes), $a_{\mathrm{CDOM}}(400)$ makes up a large proportion of the total absorption of light in water (Kowalczuk, 2001; Ficek, 2013).

The interdependence of spectral CDOM absorption values was assessed by Kowalczuk (2001), who analyzed the linear cross-correlation matrix between $a_{\mathrm{CDOM}}(\lambda)$ values measured at different wavelengths. The linear interrelationship between $a_{\mathrm{CDOM}}(\lambda)$ deteriorated with increasing spectral distance from the reference wavelength towards both shorter and longer wavelengths. To better reflect the nonlinear property of the CDOM absorption spectrum, we used a secondorder polynomial model based on log-transformed $a_{\mathrm{CDOM}}(\lambda)$ values as the input variable. The calculations were performed in the $240-700 \mathrm{~nm}$ spectral range with a $5 \mathrm{~nm}$ resolution. The statistical analyses yielded the formula

$$
\begin{aligned}
& a_{\mathrm{CDOM}}(\lambda)= \\
& 10^{\left(M(\lambda)\left(\log \left(a_{\mathrm{CDOM}}(400)\right)^{2}+N(\lambda) \log \left(a_{\mathrm{CDOM}}(400)\right)+O(\lambda)\right)\right.},
\end{aligned}
$$

where $M(\lambda)(\mathrm{m}), N(\lambda)$ (dimensionless) and $O(\lambda)\left(\mathrm{m}^{-1}\right)$ are the parameterization coefficients illustrated in Fig. 6 . Their values for the $240-700 \mathrm{~nm}$ range are listed in Table B (in Appendix A).

The spectral shapes of the regression coefficients $M(\lambda)$, $N(\lambda)$ and the free-term $O(\lambda)$, which were derived for the empirical model using the $a_{\mathrm{CDOM}}(400)$ value as an independent variable, were quite similar to the spectral shapes of the regression coefficient and the free term of the model based on chlorophyll a concentration. $M(\lambda)$ and $N(\lambda)$ were also characterized by maxima located in the red part of the spectrum. As in the first model, the spectral shape of the freeterm $O(\lambda)$ resembled the log-transformed CDOM absorption spectrum. The spectral distribution of the determination coefficient $R^{2}$ indicated that the approximation of $a_{\mathrm{CDOM}}(\lambda)$ values based on the magnitude of CDOM absorption at the reference wavelength was much more accurate than that based on chlorophyll $a$ concentration. The $R^{2}$ values were $>0.9$ in the ultraviolet part of the spectrum approaching 1 , near the reference value, but dropped to $<0.8$ at $560 \mathrm{~nm}$.

The result of the uncertainty analysis of the second model at the same wavelengths is summarized in Table 4 and presented in Fig. 7. The estimated and measured $a_{\mathrm{CDOM}}(\lambda)$ values at six wavelengths are compared in the upper six panels of Fig. 7a-f, and histograms of the ratio between estimated and measured values at the same wavelength are shown in the lower six panels of Fig. $7 \mathrm{~g}-1$. The deterioration of model performance with increasing wavelength was much smaller than in the case of the CDOM absorption spectrum approximation based on the chlorophyll $a$ concentration. The overall uncertainty expressed by arithmetic and logarithmic statistics was much better up to $550 \mathrm{~nm}$. As in the first model, both systematic and statistical estimation errors increased at longer wavelengths. The arithmetic systematic error increased from $0.38 \%$ at $260 \mathrm{~nm}$ to $16.64 \%$ at $600 \mathrm{~nm}$, and the arithmetic statistical error increased from $9.11 \%$ at $260 \mathrm{~nm}$ to $67.45 \%$ 

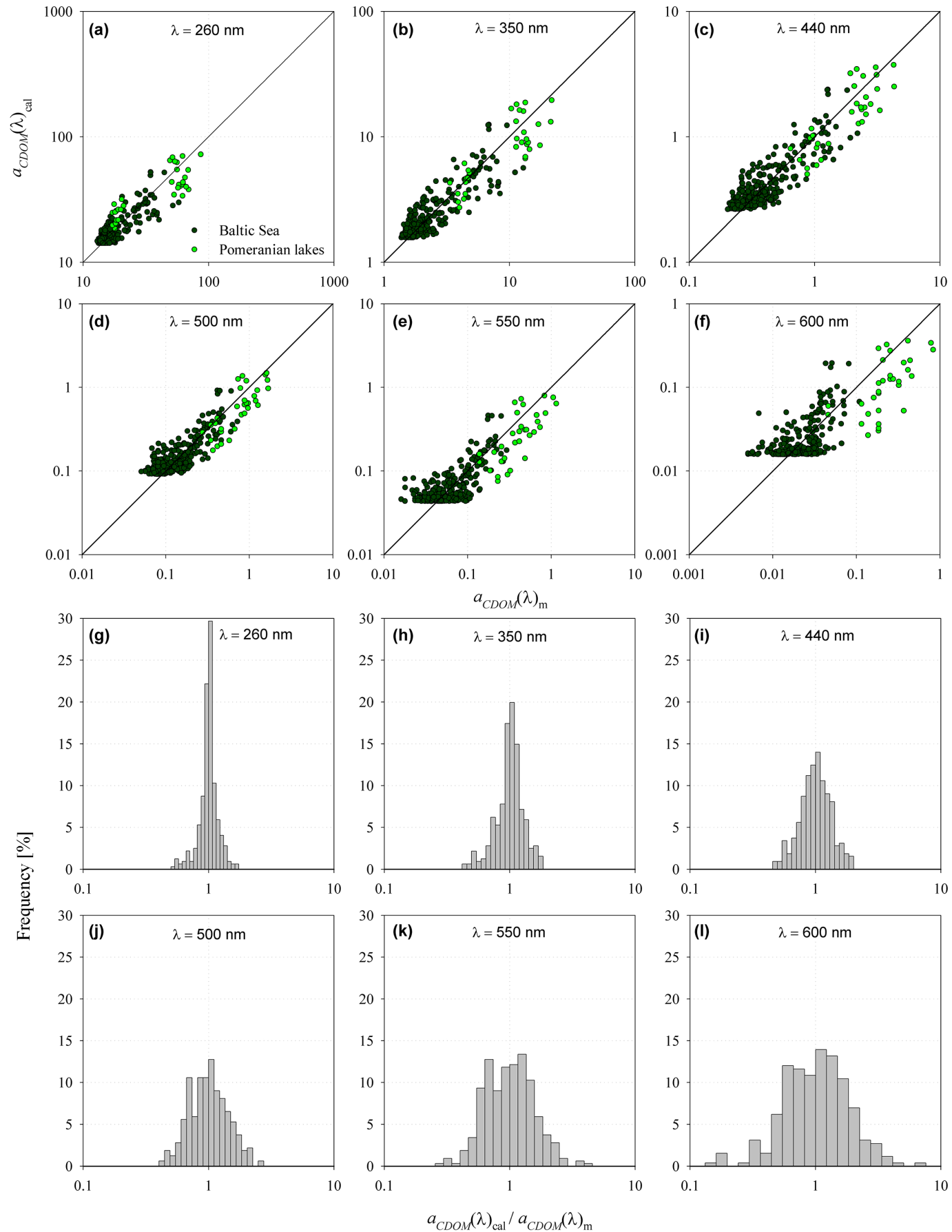

Figure 5. Comparison of light absorption coefficients measured $\left(a_{\mathrm{CDOM}}(\lambda)_{\mathrm{m}}\right)$ and calculated $\left(a_{\mathrm{CDOM}}(\lambda)_{\mathrm{cal}}\right)$ using model (Eq. 13) in the Baltic (black dots) and Pomeranian lakes (green dots) for selected wavelengths: (a) $260 \mathrm{~nm}$; (b) $350 \mathrm{~nm}$; (c) $440 \mathrm{~nm}$; (d) $500 \mathrm{~nm}$; (e) $550 \mathrm{~nm}$; (f) $600 \mathrm{~nm}$. The solid line shows the function $a_{\mathrm{CDOM}}(\lambda)_{\mathrm{cal}}=a_{\mathrm{CDOM}}(\lambda)_{\mathrm{m}}$. The probability density distributions of the ratio of calculated $a_{\mathrm{CDOM}}(\lambda)_{\text {cal }}$ to measured $a_{\mathrm{CDOM}}(\lambda)_{\mathrm{m}}$ light absorption coefficients for selected wavelengths: (g) $260 \mathrm{~nm} ;(\mathbf{h}) 350 \mathrm{~nm} ;(\mathbf{i}) 440 \mathrm{~nm} ;(\mathbf{j}) 500 \mathrm{~nm}$; (k) $550 \mathrm{~nm}$; (l) $600 \mathrm{~nm}$.

at $600 \mathrm{~nm}$. Logarithmic uncertainty metrics indicated that the standard error factor estimated for the entire spectral range from 240 to $700 \mathrm{~nm}$ of light absorption coefficients varied from 1.09 to 1.76 . This meant that the statistical logarithmic error varied from -43 to $+75 \%$. The systematic error in the 240-700 nm interval did not exceed $2 \%$. 
Table 3. Relative errors of the empirical model given by Eq. (13) for determining spectral values of CDOM absorption coefficients $\left(a_{\mathrm{CDOM}}(\lambda)\right)$ at selected wavelengths.

\begin{tabular}{crr|rrrr}
\hline & \multicolumn{2}{c|}{ Arithmetic statistics } & \multicolumn{4}{c}{ Logarithmic statistics } \\
\cline { 2 - 7 } Wavelength $(\mathrm{nm})$ & $\begin{array}{rrrr}\text { Systematic error } \\
(\varepsilon)(\%)\end{array}$ & Statistical error & $\begin{array}{r}\text { Systematic error } \\
\sigma_{\varepsilon}(\%)\end{array}$ & $\begin{array}{r}\text { Standard error } \\
\text { factor } x\end{array}$ & \multicolumn{2}{c}{ Statistical error } \\
$\sigma_{+}(\%)$ & $\sigma_{-}(\%)$ \\
\hline 260 & 1.47 & 17.03 & 0.00 & 1.19 & 19.06 & -16.01 \\
350 & 3.13 & 25.16 & -0.01 & 1.29 & 29.01 & -22.49 \\
440 & 4.01 & 29.37 & -0.01 & 1.33 & 32.71 & -24.65 \\
500 & 6.54 & 39.43 & 0.01 & 1.42 & 42.45 & -29.80 \\
550 & 11.03 & 55.07 & 0.00 & 1.57 & 57.40 & -36.47 \\
600 & 19.54 & 79.13 & -0.09 & 1.83 & 83.43 & -45.48 \\
\hline
\end{tabular}

Table 4. Relative errors of the empirical model given by Eq. (14) for determining spectral values of CDOM absorption coefficients $\left(a_{\mathrm{CDOM}}(\lambda)\right)$ at selected wavelengths.

\begin{tabular}{crr|rrrr}
\hline & \multicolumn{2}{c|}{ Arithmetic statistics } & \multicolumn{4}{c}{ Logarithmic statistics } \\
\cline { 2 - 7 } Wavelength $(\mathrm{nm})$ & $\begin{array}{r}\text { Systematic error } \\
(\varepsilon)(\%)\end{array}$ & Statistical error & $\begin{array}{r}\text { Systematic error } \\
(\varepsilon)_{g}(\%)\end{array}$ & $\begin{array}{r}\text { Standard error } \\
\text { factor } x\end{array}$ & \multicolumn{2}{c}{ Statistical error } \\
$\sigma_{+}(\%)$ & $\sigma_{-}(\%)$ \\
\hline 260 & 0.38 & 9.11 & 0.00 & 1.09 & 8.94 & -8.21 \\
350 & 0.20 & 6.43 & -0.01 & 1.07 & 6.86 & -6.42 \\
440 & 0.42 & 9.51 & 0.00 & 1.09 & 9.39 & -8.59 \\
500 & 2.21 & 22.11 & 0.01 & 1.23 & 23.01 & -18.71 \\
550 & 6.24 & 37.86 & 0.00 & 1.42 & 41.79 & -29.47 \\
600 & 16.61 & 67.45 & -0.01 & 1.76 & 75.88 & -43.14 \\
\hline
\end{tabular}
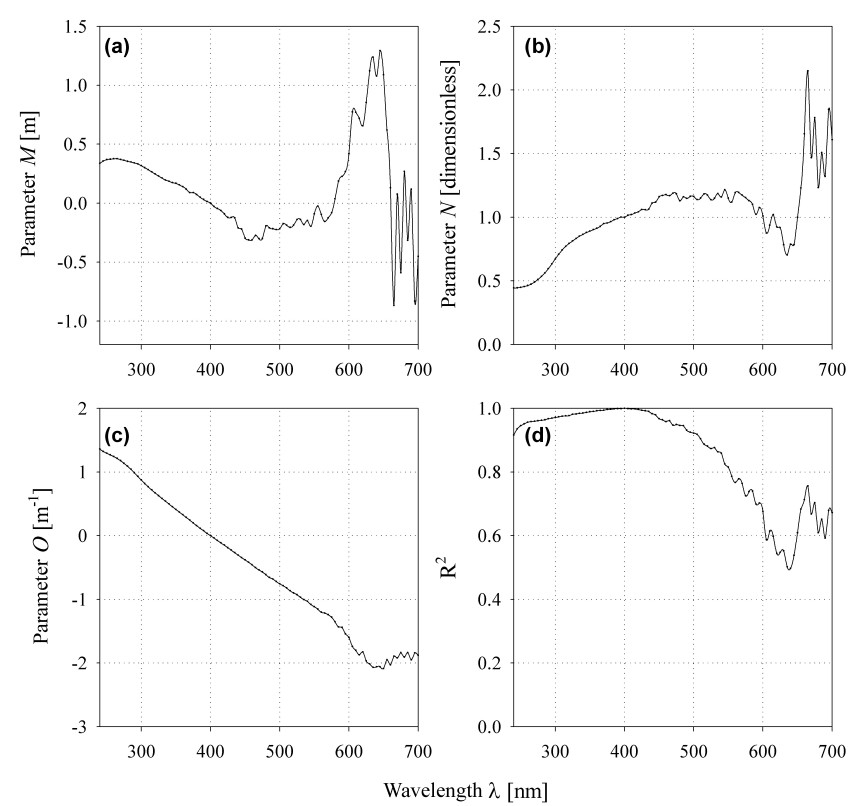

Figure 6. Spectral dependence of the model (expressed by Eq. 14) regression coefficients $(\mathbf{a}, \mathbf{b})$, free term $(\mathbf{c})$ and determination coefficient (d).

\subsection{Two-parameter model for estimating CDOM absorption in the Baltic Sea and Pomeranian lakes}

Two alternative one-parameter models of CDOM absorption were presented in the previous sections, which enabled $a_{\mathrm{CDOM}}(\lambda)$ values to be estimated with relatively small errors. For comparison, we analyzed the two-parameter model developed by Kowalczuk et al. (2006) for Baltic Sea waters. This statistical model for estimating the CDOM absorption coefficient at $375 \mathrm{~nm} a_{\mathrm{CDOM}}(375)$ in surface waters was based on the seasons and the chlorophyll $a$ concentration, which acted as a proxy for the autochthonous production of CDOM. We used the nonlinear relationship between the CDOM absorption coefficient $a_{\mathrm{CDOM}}(375)$ and the spectral slope to derive $S$ and then to reconstruct the CDOM absorption spectrum using the classical exponential model (Eq. 1).

The dependence between $S$ and $a_{\mathrm{CDOM}}$ (375) obtained by Kowalczuk et al. (2006) was overlaid on the empirical data set reported here (Fig. 8). The $S-a_{\mathrm{CDOM}}(375)$ relationship reported by Kowalczuk et al. (2006) is applicable to most of the Baltic Sea, river mouth and lake data within the $a_{\mathrm{CDOM}}(375)$ range from 1.5 to $14.16 \mathrm{~m}^{-1}$. This hyperbolic relationship did not correctly reproduce the $S$ values for $a_{\mathrm{CDOM}}(375)<1.5 \mathrm{~m}^{-1}$, however. The spectral slopes measured in open and coastal Baltic waters lay below the model curve. We propose a similar hyperbolic, statistically signif- 

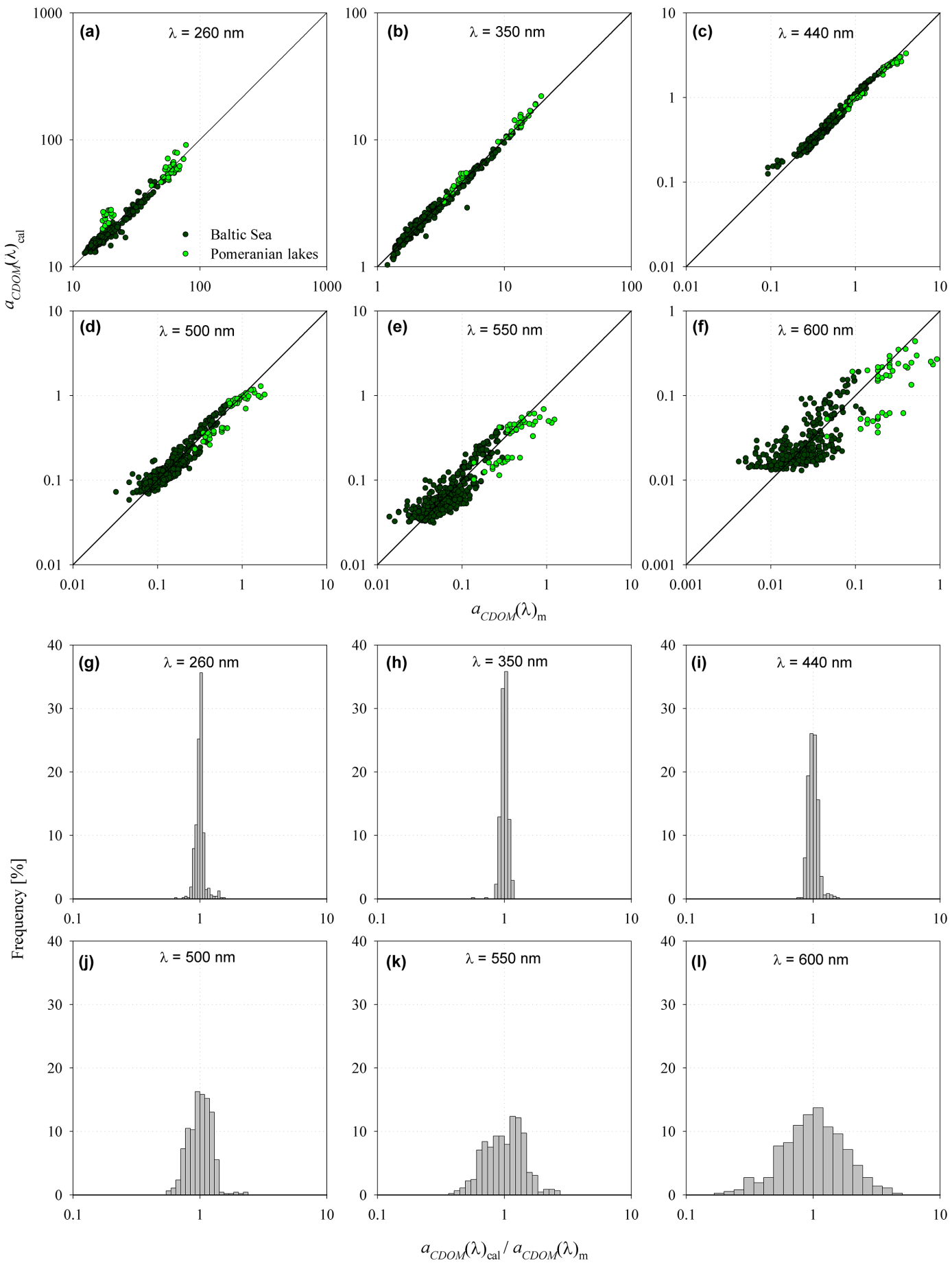

Figure 7. Comparison of light absorption coefficients measured $\left(a_{\mathrm{CDOM}}(\lambda)_{\mathrm{m}}\right)$ and calculated $\left(a_{\mathrm{CDOM}}(\lambda)_{\mathrm{cal}}\right)$ using model (Eq. 14) in the Baltic (black dots) and Pomeranian lakes (green dots) for selected wavelengths: (a) $260 \mathrm{~nm}$; (b) $350 \mathrm{~nm}$; (c) $440 \mathrm{~nm}$; (d) $500 \mathrm{~nm}$; (e) $550 \mathrm{~nm}$; (f) $600 \mathrm{~nm}$. The solid line represents the function $a_{\mathrm{CDOM}}(\lambda)_{\mathrm{cal}}=a_{\mathrm{CDOM}}(\lambda)_{\mathrm{m}}$. The probability density distribution of the ratio of calculated $a_{\mathrm{CDOM}}(\lambda)_{\text {cal }}$ to measured $a_{\mathrm{CDOM}}(\lambda)_{\mathrm{m}}$ light absorption coefficients for selected wavelengths: (g) $260 \mathrm{~nm}$; (h) $350 \mathrm{~nm}$; (i) $440 \mathrm{~nm} ;(\mathbf{j}) 500 \mathrm{~nm}$; (k) $550 \mathrm{~nm}$; (l) $600 \mathrm{~nm}$.

icant relationship between $S$ and $a_{\mathrm{CDOM}}(375)$ which could better fit the present data set. The determination coefficient of the updated hyperbolic function was very high: $R^{2}=0.86$,
$\mathrm{RMSE}=0.08 \%, n=541, p<0.0001$. The new empirical relationship between the spectral slope $S$ and $a_{\mathrm{CDOM}}(375)$ is 
Table 5. Relative errors of the empirical models given by Eqs. (15) and (1) for determining spectral values of CDOM absorption coefficients $\left(a_{\mathrm{CDOM}}(\lambda)\right)$ at selected wavelengths.

\begin{tabular}{crr|rrrr}
\hline & \multicolumn{2}{c|}{ Arithmetic statistics } & \multicolumn{3}{c}{ Logarithmic statistics } \\
\cline { 2 - 7 } Wavelength $(\mathrm{nm})$ & $\begin{array}{r}\text { Systematic error } \\
(\varepsilon)(\%)\end{array}$ & Statistical error & $\begin{array}{r}\text { Systematic error } \\
(\varepsilon)_{g}(\%)\end{array}$ & $\begin{array}{r}\text { Standard error } \\
\text { factor } x\end{array}$ & $\begin{array}{c}\text { Statistical error } \\
\sigma_{+}(\%)\end{array}$ & $\sigma_{-}(\%)$ \\
\hline 260 & 2.81 & 14.14 & 1.82 & 1.15 & 15.33 & -13.29 \\
350 & 3.69 & 4.46 & 3.59 & 1.04 & 4.49 & -4.30 \\
440 & -14.74 & 14.13 & -15.86 & 1.18 & 17.53 & -14.92 \\
500 & -31.15 & 22.06 & -34.44 & 1.37 & 36.54 & -26.76 \\
550 & -43.73 & 31.25 & -50.93 & 1.67 & 67.41 & -40.27 \\
600 & -36.05 & 50.48 & -50.16 & 2.01 & 101.01 & -50.25 \\
\hline Kowalczuk et al. (2006) & & & & & & \\
\hline 260 & 9.32 & 11.48 & 8.62 & 1.13 & 13.02 & -11.52 \\
350 & 5.14 & 4.70 & 5.04 & 1.05 & 4.68 & -4.47 \\
440 & -18.16 & 13.96 & -19.29 & 1.18 & 17.90 & -15.18 \\
500 & -35.34 & 21.93 & -38.71 & 1.38 & 38.23 & -27.66 \\
550 & -47.27 & 27.17 & -53.46 & 1.65 & 64.71 & -39.29 \\
600 & -41.25 & 46.17 & -54.77 & 2.05 & 104.97 & -51.21 \\
\hline
\end{tabular}

given by Eq. (15):

$S=0.01722+\frac{0.0057}{0.0407+a_{\mathrm{CDOM}}(375)}$.

The new formula was applied to Eq. (1) to calculate the CDOM absorption spectrum in the spectral range between 240 and $700 \mathrm{~nm}$. The results of the uncertainty analysis of the exponential model, which used the spectral slope variable estimated from the approximation given by Equation 15, are summarized in Table 5. For comparison, we also carried out an uncertainty analysis of the exponential model with the spectral slope estimated from the $S$ and $a_{\mathrm{CDOM}}$ (375) relationships given by Kowalczuk et al. (2006). This analysis revealed that the two-parameter estimate of the CDOM absorption spectrum was less accurate than the two one-parameter models. The spectral values of CDOM absorption estimated from the exponential relationship and spectral slope parameterization using the empirical formulas of Kowalczuk et al. (2006) and the present one were systematically overestimated in the UV and underestimated in the visible spectral range. The systematic and statistical errors increased towards the red part of the spectrum. The highest uncertainties, exceeding $30 \%$ in the systematic error and $20 \%$ in the statistical error, were noted at wavelengths $<500 \mathrm{~nm}$. The use of the present empirical spectral slope parameterization enabled $a_{\mathrm{CDOM}}(\lambda)$ to be estimated with relatively smaller errors, compared to the results obtained by the same approach using the slope parameterization of Kowalczuk et al. (2006).

\section{Discussion}

The dataset presented here is a subset of the almost 25-yearlong series of bio-optical data collected by IOPAN in the

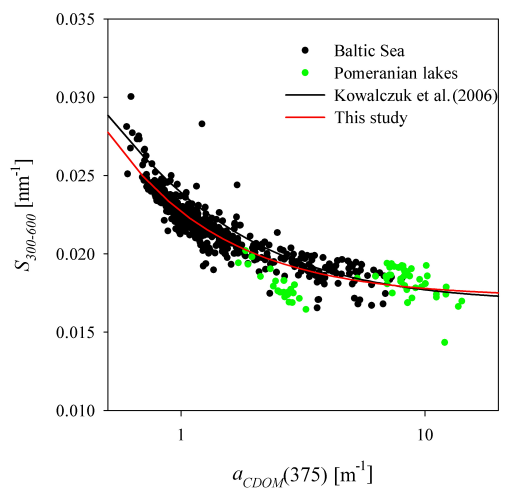

Figure 8. The relationship between the spectral slope coefficient $S$ and $a_{\mathrm{CDOM}}(375)$ in the Baltic (black dots) and lakes (green dots). The black line indicates the model of Kowalczuk et al. (2006) and the red one our new approximation (Eq. 15).

Baltic Sea. This subset matched the measurements obtained in Pomeranian lakes in 2006-2009 by Ficek et al. (2012) and Ficek (2013). These data exhibit a wide range of dynamic variability, which in some cases exceeds 3 orders of magnitude. The sea and lake water data were pooled and analyzed jointly, despite certain differences in the compositions of the optically active components in these waters. We treated the lakes as a natural extension of marine waters with optical properties resembling the properties of estuaries. Chlorophyll $a$ concentrations and $a_{\mathrm{CDOM}}(\lambda)$ values varied over 3 orders of magnitude: Chl $a$ from 0.72 to $119 \mathrm{mg} \mathrm{m}^{-3}$, $a_{\mathrm{CDOM}}(375)$ from 0.41 to $14.16 \mathrm{~m}^{-1}$ and $a_{\mathrm{CDOM}}(400)$ from 0.15 to $8.85 \mathrm{~m}^{-1}$. The spectral slope $S_{300-600}$ in Baltic Sea and lakes ranged from 0.007 to $0.03 \mathrm{~nm}^{-1}$. The variability ranges of these parameters correspond to the figures given 
in earlier works on the optical properties of Baltic Sea waters (Babin et al., 2003; Kowalczuk, 1999; Kowalczuk et al., 2005a, 2006, 2010, 2015) and Pomeranian lakes (Ficek et al., 2012; Ficek, 2013). Ficek (2013) reported that Chl $a$ may be as high as $336 \mathrm{mg} \mathrm{m}^{-3}$ in Pomeranian lakes.

\subsection{Assessment of the accuracy of one-parameter models for approximating the CDOM light absorption spectrum}

The first two models, each based on a single independent variable, were characterized by a similar arithmetic systematic error. The arithmetic systematic errors calculated for the model which used Chl $a$ as the independent variable (Eq. 13) were of the order of $1.5-7 \%$ in the UV and the visible spectral range up to $500 \mathrm{~nm}$. The arithmetic systematic error calculated for the model using $a_{\mathrm{CDOM}}(400)$ as the independent variable (Eq. 14) was of the order of $0.2-2.2 \%$ in the same spectral ranges. Based on the arithmetic metrics listed in Tables 3 and 4 for the model (Eq. 14), we concluded that the $a_{\mathrm{CDOM}}(400)$ independent-variable model had a smaller uncertainty and higher spectral values of the determination coefficient. Likewise, the standard error factor in the Chl $a$-based model was higher than in the one based on $a_{\mathrm{CDOM}}(400)$.

Comparison of the data presented in Tables 3, 4 and 5 showed that the accuracy of estimation deteriorated at wavelengths longer than $550 \mathrm{~nm}$. The precision of the CDOM measurements might offer a possible explanation. The use of $5 \mathrm{~cm}$ cuvettes enabled reliable detection of CDOM absorption at $a_{\mathrm{CDOM}}(\lambda)<0.046 \mathrm{~m}^{-1}$. The spectrophotometer's detection limit was usually reached at wavelengths $<550 \mathrm{~nm}$ in samples of open Baltic Sea waters. Therefore, modeled values were usually compared to measured values that were heavily impacted by measurement error accuracy. One way of increasing the spectrophotometric accuracy of CDOM absorption measurements would involve increasing the cuvette path length (the maximum cuvette path length used in most desktop spectrophotometers does not exceed $10 \mathrm{~cm}$ ). However, using long path lengths, available in optical waveguide spectrophotometer systems (0.2-2 m) (D'Sa et al., 1999; Miller et al., 2002), in optically complex waters such as the Baltic Sea and freshwater lakes would severely impact the radiometric sensitivity of any spectrophotometer in the UV spectral range.

A number of regional studies have presented the dependence between chlorophyll $a$ concentration (Chl $a$ ) and CDOM absorption $\left(a_{\mathrm{CDOM}}(\lambda)\right)$ using a parameterization similar to that described by Eq. (13) (Ferrari and Tassan, 1992; Tassan 1994; Vodacek et al., 1997; Morel et al., 2007; Morel and Gentili, 2009; Bricaud et al., 2010; Organelli et al., 2014). We compared the $a_{\mathrm{CDOM}}(\lambda)-\mathrm{Chl} a$ relationship that we derived with some of the relationships between $a_{\mathrm{CDOM}}(\lambda)$ and Chl $a$ derived by various authors for different water types. Selected model outputs were overlaid on the observed distribution of $a_{\mathrm{CDOM}}(\lambda)$ as a function of Chl $a$ (Fig. 9). In all cases, these relationships were approximated by power functions and assumed different rates of increase in $a_{\mathrm{CDOM}}(\lambda)$ with increasing Chl $a$ (Tassan, 1994; Morel et al., 2007; Morel and Gentili, 2009; Bricaud et al., 2010). The relationships derived by other authors were found unsuitable for estimating CDOM absorption in the Baltic Sea and lake waters. The empirical relationships derived by Tassan (1994), Morel et al. (2007), Morel and Gentili (2009) and Bricaud et al. (2010) all underestimated CDOM absorption in the Baltic Sea. Such a great discrepancy between estimated and observed CDOM absorption values has resulted from the fact that these relationships were developed for clear oceanic waters, where the contribution of dissolved organic material to the total light absorption was less than in the Baltic Sea and the concentration of Chl $a$ did not exceed $40 \mathrm{mg} \mathrm{m}^{-3}$. For example, Bricaud et al. (2010) based their empirical model on measurements from mesotrophic waters around the Marquesas Islands to hyperoligotrophic waters in the subtropical gyre and eutrophic waters in the upwelling area west off the Chilean coast (South Pacific). The Chl $a$ concentrations they reported spanned more than 2 orders of magnitude $\left(0.017\right.$ to $\left.1.5 \mathrm{mg} \mathrm{m}^{-3}\right)$ in the surface layer; values of the spectral slope $S$ lay within the $0.007-0.032 \mathrm{~nm}^{-1}$ range, and the $a_{\mathrm{CDOM}}(440)$ values were from 0.0003 to $0.038 \mathrm{~m}^{-1}$. Morel et al. (2007) carried out measurements in hyperoligotrophic waters in the South Pacific gyre (near Easter Island), where Chl $a$ concentrations ranged from 0.022 to $0.032 \mathrm{mg} \mathrm{m}^{-3}$ in the surface layer. Tassan (1994) reported two relationships between $a_{\mathrm{CDOM}}(\lambda)$ and Chl $a$ (one for Gulf of Naples waters and a second for the Adriatic Sea) and then used these relationships to estimate CDOM absorption coefficients at different ranges of Chl $a\left(0.25\right.$ do $\left.40 \mathrm{mg} \mathrm{m}^{-3}\right)$. Morel and Gentili (2009) tested a satellite ocean color algorithm they derived for determining CDOM absorption and Chl $a$ concentrations from satellite imagery of Mediterranean waters, where Chl $a$ varied from 0.01 to $0.5 \mathrm{mg} \mathrm{m}^{-3}$. The eutrophic Baltic Sea waters and supereutrophic lake waters were characterized by significantly higher Chl $a$ concentrations. The total absorption in our study area was dominated by the absorption of CDOM (Woźniak et al., 2011; Ficek et al., 2012): therefore, measured $a_{\mathrm{CDOM}}(\lambda)$ values per unit chlorophyll $a$ concentration were almost twice as high in the Baltic Sea and Pomeranian lakes as in the Pacific Ocean and Mediterranean and Adriatic Sea waters. These findings underline the need to derive regional algorithms and bio-optical models because those derived for other regions do not account for the constant, very high background CDOM absorption prevalent in the Baltic Sea and freshwater in the temperate climatic zone.

The uncertainty analysis showed that both the mathematical, single independent-variable CDOM absorption estimates presented in this paper performed better than the classical exponential model, with variable slope parameterized with the relationship derived by Kowalczuk et al. (2006) and its modification given in Eq. (15). The two-parameter exponen- 
tial model significantly underestimated $a_{\mathrm{CDOM}}(\lambda)$ at longer wavelengths. The standard error factor $x$ was lower in the Kowalczuk et al. (2006) model and our modification of this model than in approximations Eqs. (13) and (14). But the systematic errors, both arithmetic and logarithmic, were much higher. For example, in the model by Kowalczuk et al. (2006) for the $440 \mathrm{~nm}$ wavelength, the arithmetic systematic error took an average value of $-16 \%$ and the average logarithmic systematic error was $-17 \%$, whereas with Eq. (13) we had 4 and $0.01 \%$ and with Eq. (14) 0.4 and $0.003 \%$, respectively. Morel and Gentili (2009) and Morel et al. (2010) derived a two-component model for describing CDOM absorption properties, modeling the spectral slope values using its empirical relationship with the chlorophyll $a$ concentration. These models were based on data sets collected in clear oceanic waters, so their applicability to Baltic Sea conditions would probably be questionable, as in the case of the $a_{\mathrm{CDOM}}(\lambda)-\mathrm{Chl} a$ relationships.

\subsection{Assessment of the accuracy of two-parameter models for approximating the CDOM light absorption spectrum}

Finally, we compared the performance in the retrieval of the CDOM absorption spectrum in Baltic Sea conditions of three standard exponential models broadly used in optical oceanography: (i) the one by Bricaud et al. (1981), with spectral slope $S_{375-500}$ and CDOM absorption reference wavelength $\lambda_{0}=375 \mathrm{~nm}$; (ii) the one by Babin et al. (2003), with spectral slope $S_{350-500}$ and CDOM absorption reference wavelength $\lambda_{0}=443 \mathrm{~nm}$; and (iii) the model by Kowalczuk et al. (2006). The modeled spectra are presented in Fig. 10, together with measured CDOM absorption spectra and those calculated from the one-parameter models expressed by Eqs. (13) and (14) for measured Chl $a$. The empirical model developed for the Baltic Sea and inland waters (Eqs. 13 and 14), based on locally observed variabilities in biogeochemical and optical variables, adequately reflected the measured light absorption coefficients in the spectral range $240-600 \mathrm{~nm}$. The model based on the dependence of the chlorophyll $a$ concentration, Eq. (13), fitted the $a_{\mathrm{CDOM}}(\lambda)$ from 240 to $600 \mathrm{~nm}$ best and could be applied to a variety of water bodies with contrasting trophic status. From this point of view, it outperformed the models derived by Bricaud et al. (1981) and Babin et al. (2003), which were developed for oligotrophic or mesotrophic oceanic waters and European coastal waters, respectively. The model by Kowalczuk et al. (2006) underestimated $a_{\mathrm{CDOM}}(\lambda)$ for Chl $a$ concentrations $<5 \mathrm{mg} \mathrm{m}^{-3}$ (see Fig. 10). For Chl $a>20 \mathrm{mg} \mathrm{m}^{-3}$ the shapes of all the modeled spectra were similar.

In order to compare the performance of the two-parameter models developed by Bricaud et al. (1981) and Babin et al. (2003), we adapted them to the empirical data set presented in this study within the spectral range from 240 to $700 \mathrm{~nm}$ and then applied the same statistical metrics to assess
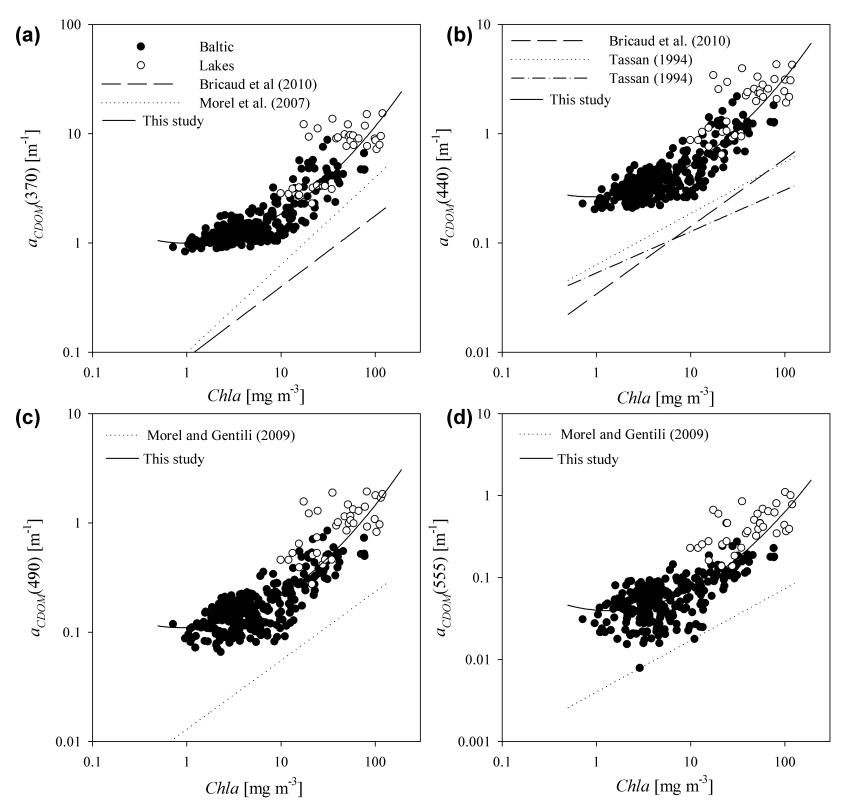

Figure 9. Comparison of the relationships between $a_{\mathrm{CDOM}}(\lambda)$ and Chl $a$ derived in this work and obtained by different authors for different waters adapted to the data analyzed in this work.

their uncertainty. The calculated errors for selected wavelengths are listed in Table 6 . The systematic errors in arithmetic statistics were higher for the models by Bricaud et al. (1981) and Babin et al. (2003) compared to the errors calculated for the parameterizations given by Eqs. (13) and (14). The systematic errors calculated for the CDOM absorption model by Babin et al. (2003) were significantly higher at all the wavelengths compared to those listed in Tables 3 and 4. CDOM absorption could be estimated using the empirical model based on the $a_{\mathrm{CDOM}}(\lambda)-\mathrm{Chl} a$ relationship with a systematic error of $3.13 \%$ at $\lambda=350 \mathrm{~nm}$, whereas the model by Babin et al. (2003) estimated CDOM absorption at the same wavelength, with a systematic error of $-33.70 \%$. The calculated statistical errors of the estimates using the models by Bricaud et al. (1981) and Babin et al. (2003) were very large compared to the results obtained with models expressed by Eqs. (13) and (14). Whereas the standard error factors are quite good for Bricaud's model (from 1 to 2.43), they are much higher for Babin's model (from 1.045 to 3.58). However, in both cases, the systematic errors are significant: -59 to 144 and -79 to $+400 \%$, respectively.

\section{Conclusions}

We demonstrated that CDOM absorption was correlated nonlinearly with chlorophyll $a$ concentration over a broad range of variability spanning 3 orders of magnitude in waters of the Baltic Sea, its estuaries, coastal lagoons and in freshwater lakes of different trophic status. A second-order polynomial approximation of the relationship between chlorophyll 

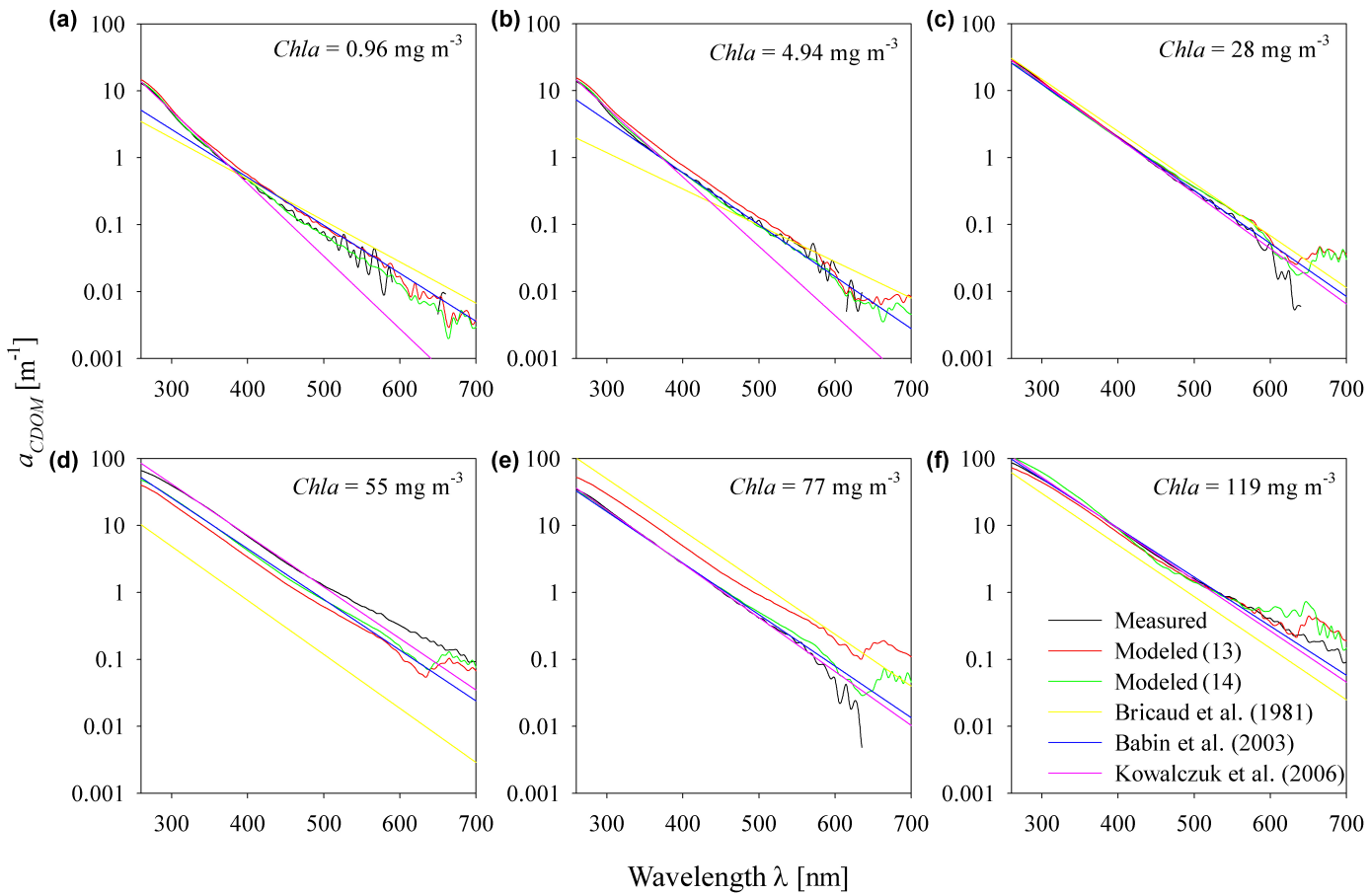

Figure 10. CDOM light absorption spectra (empirical, modeled using Eqs. (13) and (14), calculated using the models of Bricaud et al. (1981), Babin et al. (2003) and Kowalczuk et al. (2006) for the following concentrations of chlorophyll a Chl $a$ : (a) $0.96 \mathrm{mg} \mathrm{m}^{-3}$; (b) $4.94 \mathrm{mg} \mathrm{m}^{-3}$; (c) $28 \mathrm{mg} \mathrm{m}^{-3}$; (d) $55 \mathrm{mg} \mathrm{m}^{-3}$; (e) $77 \mathrm{mg} \mathrm{m}^{-3}$; (f) $119 \mathrm{mg} \mathrm{m}^{-3}$.

Table 6. Relative errors of the models of Bricaud et al. (1981) and Babin et al. (2003) for determining spectral values of CDOM absorption coefficients $\left(a_{\mathrm{CDOM}}(\lambda)\right)$ at selected wavelengths.

\begin{tabular}{|c|c|c|c|c|c|c|}
\hline \multirow[b]{2}{*}{ Wavelength (nm) } & \multicolumn{2}{|c|}{ Arithmetic statistics } & \multicolumn{4}{|c|}{ Logarithmic statistics } \\
\hline & $\begin{array}{r}\text { Systematic error } \\
(\varepsilon)(\%)\end{array}$ & $\begin{array}{r}\text { Statistical error } \\
\sigma_{\varepsilon}(\%) \\
\end{array}$ & $\begin{array}{r}\text { Systematic error } \\
(\varepsilon)_{g}(\%)\end{array}$ & $\begin{array}{r}\text { Standard error } \\
\text { factor } x\end{array}$ & $\begin{array}{l}\text { Statistic } \\
\sigma_{+}(\%)\end{array}$ & $\begin{array}{l}\text { al error } \\
\sigma_{-}(\%)\end{array}$ \\
\hline \multicolumn{7}{|l|}{ Bricaud et al. (1981) } \\
\hline 260 & -35.74 & 20.98 & -38.79 & 1.36 & 35.97 & -26.46 \\
\hline 350 & -6.95 & 3.64 & -7.02 & 1.04 & 3.98 & -3.82 \\
\hline 440 & 11.10 & 8.51 & 10.78 & 1.08 & 7.95 & -7.37 \\
\hline 500 & 14.24 & 19.13 & 12.82 & 1.17 & 16.72 & -14.32 \\
\hline 550 & 11.21 & 30.85 & 7.70 & 1.28 & 27.77 & -21.74 \\
\hline 600 & 51.80 & 90.23 & 33.10 & 1.64 & 64.00 & -39.03 \\
\hline \multicolumn{7}{|l|}{ Babin et al. (2003) } \\
\hline 260 & -58.45 & 27.26 & -65.30 & 1.78 & 77.78 & -43.75 \\
\hline 350 & -33.70 & 13.85 & -35.08 & 1.23 & 22.59 & -18.43 \\
\hline 440 & -4.69 & 4.10 & -4.78 & 1.04 & 4.45 & -4.26 \\
\hline 500 & 12.87 & 18.23 & 11.40 & 1.18 & 17.77 & -15.09 \\
\hline 550 & 26.12 & 42.51 & 19.30 & 1.40 & 40.12 & -28.63 \\
\hline 600 & 92.38 & 137.52 & 55.82 & 1.95 & 95.05 & -48.73 \\
\hline
\end{tabular}

$a$ concentration and $a_{\mathrm{CDOM}}(400)$ was used with respect to both sea and freshwater and was much more accurate than the one derived for Baltic Sea waters by Kowalczuk (2001). This relationship also demonstrated that the optical and biooptical properties of sea- and freshwater could be regarded as a continuum with regard to CDOM absorption and chlorophyll $a$ concentration. We derived models for estimating the CDOM light absorption spectrum in the spectral range 240-700 nm nonlinearly from chlorophyll $a$ concentrations (Chl $a$ ) or from coefficients of light absorption by CDOM 
for a wavelength of $400 \mathrm{~nm}\left(a_{\mathrm{CDOM}}(400)\right)$. For comparison, we also tested the classical exponential model for approximating the CDOM absorption spectrum, where the spectral slope coefficient was determined from the nonlinear relationship between the spectral slope coefficient and $a_{\mathrm{CDOM}}(375)$. The result of the uncertainty analysis showed that the oneparameter, second-order polynomial function of the chlorophyll $a$ concentration $\mathrm{Chl} a$ enabled spectral values of the CDOM absorption coefficient $a_{\mathrm{CDOM}}(\lambda)$ to be estimated with just a slightly lower accuracy than its estimate based on a second-order polynomial function of the CDOM absorption coefficient at a wavelength of $400 \mathrm{~nm} a_{\mathrm{CDOM}}(400)$. The models presented here, optimized for the specific optical and bio-optical conditions of the Baltic Sea and freshwater bodies, had significantly lower estimation errors compared to the widely used CDOM absorption models developed by other authors. The CDOM absorption models presented in this study can be used for improving remote-sensing algorithms designed for retrieving various optical and bio-optical parameters required for characterizing and monitoring the state and functioning of the Baltic Sea and Pomeranian lake ecosystems. Validation of these models showed that they can be reliably applied in monitoring surveys when a rapid approximation of the light absorption spectrum is needed.

\section{Data availability}

All data used in this study will be freely available, for scientific use only, upon request. Anyone interested in using this data set for scientific research should contact the corresponding author via e-mail. 


\section{Appendix A}

Table A1. Model parameters for light absorption by CDOM (Eq. 13) for the wavelength range 240-700 nm shown for intervals of $5 \mathrm{~nm}$.

\begin{tabular}{|c|c|c|c|c|c|c|c|c|c|}
\hline $\begin{array}{r}\text { Wavelength } \\
(\mathrm{nm})\end{array}$ & $\begin{array}{r}A \\
\left(\mathrm{~m}^{5} \mathrm{mg}^{-2}\right)\end{array}$ & $\begin{array}{r}B \\
\left(\mathrm{~m}^{2} \mathrm{mg}^{-1}\right)\end{array}$ & $\begin{array}{r}D \\
\left(\mathrm{~m}^{-1}\right)\end{array}$ & $\mathrm{R}^{2}$ & $\begin{array}{r}\text { Wavelength } \\
(\mathrm{nm})\end{array}$ & $\left(\mathrm{m}^{5} \mathrm{mg}^{-2}\right)$ & $\begin{array}{r}B \\
\left(\mathrm{~m}^{2} \mathrm{mg}^{-1}\right)\end{array}$ & $\begin{array}{r}D \\
\left(\mathrm{~m}^{-1}\right)\end{array}$ & $R^{2}$ \\
\hline 1 & 2 & 3 & 4 & 5 & 1 & 2 & 3 & 4 & 5 \\
\hline 240 & 0.200 & -0.104 & 1.286 & 0.78 & 475 & 0.262 & 0.027 & -0.857 & 0.79 \\
\hline 245 & 0.207 & -0.110 & 1.250 & 0.79 & 480 & 0.272 & 0.002 & -0.880 & 0.77 \\
\hline 250 & 0.211 & -0.114 & 1.221 & 0.80 & 485 & 0.255 & 0.057 & -0.956 & 0.79 \\
\hline 255 & 0.214 & -0.115 & 1.195 & 0.81 & 490 & 0.263 & 0.024 & -0.959 & 0.77 \\
\hline 260 & 0.216 & -0.114 & 1.166 & 0.81 & 495 & 0.264 & 0.028 & -1.003 & 0.76 \\
\hline 265 & 0.218 & -0.110 & 1.131 & 0.81 & 500 & 0.275 & 0.010 & -1.038 & 0.76 \\
\hline 270 & 0.220 & -0.107 & 1.090 & 0.82 & 505 & 0.277 & 0.005 & -1.059 & 0.76 \\
\hline 275 & 0.222 & -0.101 & 1.041 & 0.82 & 510 & 0.265 & 0.032 & -1.105 & 0.75 \\
\hline 280 & 0.230 & -0.102 & 0.990 & 0.83 & 515 & 0.290 & -0.003 & -1.147 & 0.74 \\
\hline 285 & 0.233 & -0.095 & 0.931 & 0.83 & 520 & 0.292 & -0.013 & -1.177 & 0.72 \\
\hline 290 & 0.237 & -0.088 & 0.865 & 0.83 & 525 & 0.304 & -0.050 & -1.178 & 0.73 \\
\hline 295 & 0.243 & -0.080 & 0.795 & 0.83 & 530 & 0.310 & -0.055 & -1.221 & 0.73 \\
\hline 300 & 0.249 & -0.074 & 0.727 & 0.83 & 535 & 0.313 & -0.047 & -1.275 & 0.70 \\
\hline 305 & 0.253 & -0.066 & 0.660 & 0.83 & 540 & 0.307 & -0.045 & -1.292 & 0.70 \\
\hline 310 & 0.258 & -0.061 & 0.599 & 0.83 & 545 & 0.320 & -0.054 & -1.345 & 0.70 \\
\hline 315 & 0.260 & -0.055 & 0.541 & 0.83 & 550 & 0.344 & -0.110 & -1.354 & 0.68 \\
\hline 320 & 0.261 & -0.047 & 0.487 & 0.83 & 555 & 0.344 & -0.101 & -1.398 & 0.66 \\
\hline 325 & 0.261 & -0.040 & 0.435 & 0.84 & 560 & 0.337 & -0.065 & -1.470 & 0.64 \\
\hline 330 & 0.258 & -0.027 & 0.382 & 0.84 & 565 & 0.341 & -0.087 & -1.468 & 0.67 \\
\hline 335 & 0.257 & -0.019 & 0.332 & 0.84 & 570 & 0.337 & -0.091 & -1.491 & 0.62 \\
\hline 340 & 0.260 & -0.020 & 0.286 & 0.84 & 575 & 0.314 & -0.040 & -1.537 & 0.65 \\
\hline 345 & 0.262 & -0.018 & 0.238 & 0.84 & 580 & 0.291 & 0.036 & -1.641 & 0.65 \\
\hline 350 & 0.266 & -0.024 & 0.196 & 0.83 & 585 & 0.462 & -0.307 & -1.597 & 0.65 \\
\hline 355 & 0.265 & -0.018 & 0.150 & 0.83 & 590 & 0.382 & -0.195 & -1.612 & 0.60 \\
\hline 360 & 0.268 & -0.022 & 0.108 & 0.83 & 595 & 0.367 & -0.095 & -1.776 & 0.65 \\
\hline 365 & 0.265 & -0.012 & 0.059 & 0.83 & 600 & 0.405 & -0.198 & -1.778 & 0.61 \\
\hline 370 & 0.263 & -0.002 & 0.008 & 0.83 & 605 & 0.444 & -0.251 & -1.886 & 0.52 \\
\hline 375 & 0.266 & -0.007 & -0.035 & 0.83 & 610 & 0.480 & -0.278 & -1.963 & 0.57 \\
\hline 380 & 0.266 & -0.004 & -0.081 & 0.83 & 615 & 0.516 & -0.288 & -2.083 & 0.57 \\
\hline 385 & 0.261 & 0.009 & -0.131 & 0.83 & 620 & 0.520 & -0.450 & -1.879 & 0.46 \\
\hline 390 & 0.260 & 0.014 & -0.174 & 0.83 & 625 & 0.510 & -0.337 & -2.118 & 0.50 \\
\hline 395 & 0.261 & 0.012 & -0.216 & 0.83 & 630 & 0.584 & -0.538 & -2.015 & 0.46 \\
\hline 400 & 0.260 & 0.009 & -0.248 & 0.83 & 635 & 0.553 & -0.471 & -2.075 & 0.44 \\
\hline 405 & 0.255 & 0.022 & -0.294 & 0.83 & 640 & 0.585 & -0.434 & -2.110 & 0.53 \\
\hline 410 & 0.261 & 0.008 & -0.326 & 0.83 & 645 & 0.600 & -0.487 & -2.069 & 0.51 \\
\hline 415 & 0.252 & 0.032 & -0.379 & 0.83 & 650 & 0.682 & -0.567 & -2.115 & 0.59 \\
\hline 420 & 0.248 & 0.037 & -0.418 & 0.82 & 655 & 0.572 & -0.371 & -2.096 & 0.64 \\
\hline 425 & 0.255 & 0.021 & -0.451 & 0.82 & 660 & 0.512 & -0.099 & -2.375 & 0.67 \\
\hline 430 & 0.257 & 0.016 & -0.486 & 0.82 & 665 & 0.301 & 0.387 & -2.524 & 0.72 \\
\hline 435 & 0.258 & 0.015 & -0.529 & 0.82 & 670 & 0.446 & -0.024 & -2.320 & 0.66 \\
\hline 440 & 0.253 & 0.028 & -0.577 & 0.82 & 675 & 0.319 & 0.264 & -2.428 & 0.69 \\
\hline 445 & 0.258 & 0.019 & -0.614 & 0.81 & 680 & 0.305 & 0.224 & -2.352 & 0.66 \\
\hline 450 & 0.251 & 0.036 & -0.662 & 0.80 & 685 & 0.360 & 0.072 & -2.297 & 0.62 \\
\hline 455 & 0.262 & 0.011 & -0.688 & 0.80 & 690 & 0.452 & 0.103 & -2.314 & 0.60 \\
\hline 460 & 0.271 & -0.005 & -0.723 & 0.80 & 695 & 0.191 & 0.466 & -2.481 & 0.67 \\
\hline 465 & 0.253 & 0.048 & -0.795 & 0.81 & 700 & 0.243 & 0.310 & -2.412 & 0.62 \\
\hline 470 & 0.267 & 0.014 & -0.815 & 0.80 & & & & & \\
\hline
\end{tabular}




\section{Appendix B}

Table B1. Parameters of the model of light absorption by CDOM (Eq. 14) for the wavelength range 240-700 nm, shown for intervals of $5 \mathrm{~nm}$.

\begin{tabular}{|c|c|c|c|c|c|c|c|c|c|}
\hline $\begin{array}{r}\text { Wavelength } \\
(\mathrm{nm})\end{array}$ & $\begin{array}{r}M \\
\left(\mathrm{~m}^{5} \mathrm{mg}^{-2}\right)\end{array}$ & $\begin{array}{r}N \\
\left(\mathrm{~m}^{2} \mathrm{mg}^{-1}\right)\end{array}$ & $\begin{array}{r}O \\
\left(\mathrm{~m}^{-1}\right)\end{array}$ & $\mathrm{R}^{2}$ & $\begin{array}{r}\text { Wavelength } \\
(\mathrm{nm})\end{array}$ & $\begin{array}{r}M \\
\left(\mathrm{~m}^{5} \mathrm{mg}^{-2}\right)\end{array}$ & $\begin{array}{r}N \\
\left(\mathrm{~m}^{2} \mathrm{mg}^{-1}\right)\end{array}$ & $\begin{array}{r}O \\
\left(\mathrm{~m}^{-1}\right)\end{array}$ & $R^{2}$ \\
\hline 1 & 2 & 3 & 4 & 5 & 1 & 2 & 3 & 4 & 5 \\
\hline 240 & 0.337 & 0.444 & 1.360 & 0.92 & 475 & -0.300 & 1.184 & -0.572 & 0.95 \\
\hline 245 & 0.356 & 0.445 & 1.323 & 0.94 & 480 & -0.195 & 1.129 & -0.613 & 0.95 \\
\hline 250 & 0.369 & 0.450 & 1.294 & 0.95 & 485 & -0.211 & 1.159 & -0.657 & 0.95 \\
\hline 255 & 0.372 & 0.455 & 1.269 & 0.95 & 490 & -0.217 & 1.147 & -0.682 & 0.93 \\
\hline 260 & 0.375 & 0.463 & 1.243 & 0.96 & 495 & -0.226 & 1.163 & -0.720 & 0.93 \\
\hline 265 & 0.376 & 0.474 & 1.213 & 0.96 & 500 & -0.218 & 1.163 & -0.756 & 0.92 \\
\hline 270 & 0.370 & 0.490 & 1.177 & 0.96 & 505 & -0.176 & 1.138 & -0.787 & 0.92 \\
\hline 275 & 0.363 & 0.511 & 1.136 & 0.96 & 510 & -0.187 & 1.150 & -0.823 & 0.90 \\
\hline 280 & 0.355 & 0.535 & 1.091 & 0.96 & 515 & -0.206 & 1.183 & -0.867 & 0.89 \\
\hline 285 & 0.348 & 0.562 & 1.042 & 0.96 & 520 & -0.188 & 1.174 & -0.901 & 0.88 \\
\hline 290 & 0.340 & 0.596 & 0.988 & 0.97 & 525 & -0.140 & 1.137 & -0.929 & 0.87 \\
\hline 295 & 0.332 & 0.633 & 0.930 & 0.97 & 530 & -0.139 & 1.149 & -0.969 & 0.88 \\
\hline 300 & 0.317 & 0.672 & 0.873 & 0.97 & 535 & -0.182 & 1.186 & -1.005 & 0.86 \\
\hline 305 & 0.300 & 0.709 & 0.819 & 0.97 & 540 & -0.148 & 1.158 & -1.033 & 0.86 \\
\hline 310 & 0.283 & 0.743 & 0.767 & 0.98 & 545 & -0.197 & 1.215 & -1.082 & 0.83 \\
\hline 315 & 0.265 & 0.771 & 0.718 & 0.98 & 550 & -0.092 & 1.150 & -1.116 & 0.82 \\
\hline 320 & 0.247 & 0.794 & 0.673 & 0.98 & 555 & -0.025 & 1.119 & -1.155 & 0.79 \\
\hline 325 & 0.229 & 0.813 & 0.628 & 0.98 & 560 & -0.097 & 1.192 & -1.204 & 0.77 \\
\hline 330 & 0.212 & 0.833 & 0.584 & 0.98 & 565 & -0.157 & 1.195 & -1.217 & 0.78 \\
\hline 335 & 0.195 & 0.851 & 0.541 & 0.98 & 570 & -0.126 & 1.174 & -1.243 & 0.76 \\
\hline 340 & 0.185 & 0.865 & 0.497 & 0.99 & 575 & -0.081 & 1.154 & -1.282 & 0.73 \\
\hline 345 & 0.174 & 0.880 & 0.454 & 0.99 & 580 & 0.036 & 1.130 & -1.355 & 0.74 \\
\hline 350 & 0.167 & 0.890 & 0.411 & 0.99 & 585 & 0.187 & 1.101 & -1.434 & 0.74 \\
\hline 355 & 0.154 & 0.902 & 0.370 & 0.99 & 590 & 0.227 & 1.022 & -1.444 & 0.70 \\
\hline 360 & 0.139 & 0.913 & 0.328 & 0.99 & 595 & 0.267 & 1.075 & -1.543 & 0.70 \\
\hline 365 & 0.119 & 0.928 & 0.286 & 0.99 & 600 & 0.420 & 1.009 & -1.601 & 0.68 \\
\hline 370 & 0.089 & 0.950 & 0.244 & 0.99 & 605 & 0.774 & 0.876 & -1.742 & 0.59 \\
\hline 375 & 0.089 & 0.955 & 0.200 & 1.00 & 610 & 0.771 & 0.937 & -1.804 & 0.61 \\
\hline 380 & 0.073 & 0.965 & 0.157 & 1.00 & 615 & 0.719 & 1.020 & -1.873 & 0.60 \\
\hline 385 & 0.050 & 0.979 & 0.115 & 1.00 & 620 & 0.656 & 0.924 & -1.827 & 0.54 \\
\hline 390 & 0.030 & 0.990 & 0.076 & 1.00 & 625 & 0.853 & 0.918 & -1.969 & 0.55 \\
\hline 395 & 0.014 & 1.001 & 0.035 & 1.00 & 630 & 1.122 & 0.784 & -2.016 & 0.55 \\
\hline 400 & 0.000 & 1.000 & 0.000 & 1.00 & 635 & 1.238 & 0.704 & -2.069 & 0.50 \\
\hline 405 & -0.029 & 1.015 & -0.038 & 1.00 & 640 & 1.078 & 0.787 & -2.061 & 0.50 \\
\hline 410 & -0.046 & 1.021 & -0.075 & 1.00 & 645 & 1.293 & 0.784 & -2.060 & 0.54 \\
\hline 415 & -0.063 & 1.033 & -0.115 & 1.00 & 650 & 1.090 & 0.999 & -2.088 & 0.61 \\
\hline 420 & -0.092 & 1.042 & -0.151 & 1.00 & 655 & 0.620 & 1.229 & -1.952 & 0.68 \\
\hline 425 & -0.122 & 1.060 & -0.190 & 0.99 & 660 & 0.130 & 1.655 & -2.029 & 0.71 \\
\hline 430 & -0.123 & 1.059 & -0.228 & 0.99 & 665 & -0.868 & 2.149 & -1.893 & 0.76 \\
\hline 435 & -0.125 & 1.063 & -0.269 & 0.99 & 670 & 0.075 & 1.468 & -1.922 & 0.67 \\
\hline 440 & -0.210 & 1.111 & -0.307 & 0.98 & 675 & -0.590 & 1.782 & -1.839 & 0.70 \\
\hline 445 & -0.221 & 1.118 & -0.346 & 0.98 & 680 & 0.268 & 1.233 & -1.910 & 0.61 \\
\hline 450 & -0.297 & 1.161 & -0.382 & 0.97 & 685 & -0.316 & 1.508 & -1.839 & 0.65 \\
\hline 455 & -0.312 & 1.171 & -0.419 & 0.96 & 690 & 0.117 & 1.321 & -1.951 & 0.59 \\
\hline 460 & -0.314 & 1.177 & -0.458 & 0.96 & 695 & -0.832 & 1.847 & -1.843 & 0.68 \\
\hline 465 & -0.275 & 1.169 & -0.503 & 0.96 & 700 & -0.453 & 1.610 & -1.882 & 0.67 \\
\hline 470 & -0.302 & 1.190 & -0.540 & 0.95 & & & & & \\
\hline
\end{tabular}


Acknowledgements. This paper was produced as a part of project N N306 041136 financed by the Polish Ministry of Science and Higher Education in 2009-2014 and also within the framework of the SatBałtyk project funded by the European Union through the European Regional Development Fund, (no. POIG.01.01.02-22011/09, "The Satellite Monitoring of the Baltic Sea Environment"). The Institute of Oceanology, Polish Academy of Sciences, partially supported this study within the framework of the Statutory Research Project II.5.

Edited by: O. Zielinski

Reviewed by: two anonymous referees

\section{References}

Arrigo, K. and Brown, C.: Impact of chromophoric dissolved organic matter on UV inhibition of primary productivity in the sea, Mar. Ecol.-Prog. Ser., 140, 207-216, 1996.

Babin, M., Stramski, D., Ferrari, G. M., Claustre, H., Bricaud, A., Obolensky, G., and Hoepffner, N.: Variations in the light absorption coefficient of phytoplankton, nonalgal particles, and dissolved organic matter in coastal waters around Europe, J. Geophys. Res., 108, 3211, doi:10.1029/2001JC000882, 2003.

Bricaud, A., Morel, A., and Prieur L.: Absorption by dissolved organic matter of the sea (yellow substance) in the UV and visible domains, Limnol. Oceanogr., 26, 43-53, 1981.

Bricaud, A., Babin, M., Claustre, H., Ras, J., and Tièche, S.: Light absorption properties and absorption budget of Southeast Pacific waters, J. Geophys, Res. 115, C08009, doi:10.1029/2009JC005517, 2010.

Brezonik, P. L., Olmanson, L. G., Finlay, J. C., and Bauer, M. E.: Factors affecting the measurement of CDOM by remote sensing of optically complex inland waters, Remote Sens. Environ., 157, 199-215, 2015.

Campanelli, A., Bulatovic, A., Cabrini, M., Grilli, F., Kljajić, Z., Mosetti, R., Paschini, E., Penna, P., and Marini, M.: Spatial distribution of physical, chemical and biological oceanographic properties, phytoplankton, nutrients and Coloured Dissolved Organic Matter (CDOM) on the Boka Kotorska Bay (Adriatic Sea), Geofizika, 26, 215-228, 2009.

Carlson R. E.: A trophic state index for lakes, Limnol. Oceanogr., 22, 361-369, 1977.

Chlost, I. and Cieśliński, R.: Change of level of waters Lake Łebsko, Limnol. Rev., 5, 17-26, 2005.

Choiński, A.: Physical limnology of Poland, Adam Mickiewicz University, Poznań, 547, 2007 (in Polish).

Darecki, M. and Stramski, D.: An evaluation of MODIS and SeaWiFS bio-optical algorithms in the Baltic Sea, Remote Sens. Environ., 89, 326-350, 2004.

Darecki, M., Weeks, A., Sagan, S., Kowalczuk, P., and Kaczmarek, S.: Optical characteristics of two contrasting case 2 waters and their influence on remote sensing algorithms, Cont. Shelf Res., 23, 237-250, 2003.

D’Sa, E. J., Steward, R. G., Vodacek, A., Blough, N. V., and Phinney, D.: Determining optical absorption of colored dissolved organic matter in seawater with a liquid capillary waveguide, Limnol. Oceanogr., 44, 1142-1148, 1999.
Ferrari, G. M. and Tassan, S.: Evaluation of the influence of yellow substance absorption on the remote sensing of water quality in the Gulf of Naples: a case study, Int. J. Remote Sens., 13, 2177 2189, 1992.

Ficek, D.: Bio-optical properties of lakes in Pomerania and their comparison with the properties of other lakes and Baltic Sea waters, Dissertations and Monographs IO PAS 23/2013, Institute of Oceanology Polish Academy of Sciences, 351 pp., 2013 (in Polish).

Ficek, D., Zapadka, T., and Dera, J.: Remote sensing reflectance of Pomeranian lakes and the Baltic, Oceanologia, 53, 959-970, 2011.

Ficek, D., Meler, J., Zapadka, T., Woźniak, B., and Dera, J.: Inherent optical properties and remote sensing reflectance of Pomeranian lakes (Poland), Oceanologia, 54, 611-630, 2012.

Górniak, A.: Humic substances and their role in the functioning of freshwater ecosystems, Warsaw University, Białystok Branch, 151, 1996 (in Polish).

Helms, J. R., Stubbins, A., Ritchie, J. D., Minor, E., Kieber, D. J., and Mopper, K.: Absorption spectral slopes and slope ratios as indicators of molecular weight source, and photobleaching of chromophoric dissolved organic matter, Limnol. Oceanogr., 53, 955-969, 2008.

Jerlov, N. G.: Marine Optics, Elsevier, New York, 231 pp., 1976.

Kieber, D. J., Peake, B. M., and Scully, N. M.: Reactive oxygen species in aquatic ecosystems, in: UV effects in aquatic Organisms, edited by: Helbling, E. W. and Zagarese, H., Royal Society of Chemistry, Cambridge, UK, 251-288, 2003.

Kirk, J. T. O.: Light and Photosynthesis in Aquatic Ecosystems, Cambridge University Press, London, New York, 509, 1994.

Kowalczuk, P.: Seasonal variability of yellow substances absorption in the surface layer of the Baltic Sea, J. Geophys. Res., 104, 30047-30058, 1999.

Kowalczuk, P.: Light absorption by yellow substances in Baltic Sea, Doctoral Thesis, Institute of Oceanology Polish Academy of Sciences, 2001 (in Polish).

Kowalczuk, P. and Kaczmarek, S.: Analysis of temporal and spatial variability of "yellow substance" absorption in the Southern Baltic, Oceanologia, 38, 3-32, 1996.

Kowalczuk, P., Olszewski, J., Darecki, M., and Kaczmarek, S.: Empirical relationships between coloured dissolved organic matter (CDOM) absorption and apparent optical properties in Baltic Sea waters, Int. J. Remote Sens., 26, 345-370, 2005a.

Kowalczuk, P., Stoń-Egiert, J., Cooper, W. J., Whitehead, R. F., and Durako, M. J.: Characterization of Chromophoric Dissolved Organic Matter (CDOM) in the Baltic Sea by Excitation Emission Matrix fluorescence spectroscopy, Mar. Chem., 96, 273292, 2005b.

Kowalczuk, P., Stedmon, C. A., and Markager, S.: Modeling absorption by CDOM In the Baltic Sea from season, salinity and chlorophyll, Mar. Chem., 101, 1-11, 2006.

Kowalczuk, P., Darecki, M., Zabłocka, M., and Górecka, I.: Validation of empirical and semi-analytical remote sensing algorithms for estimating absorption by Coloured Dissolved Organic Matter in the Baltic Sea from SeaWiFS and MODIS imagery, Oceanologia, 52, 171-196, 2010.

Kowalczuk, P., Sagan, S., Zabłocka, M., and Borzycka, K.: Mixing anomaly in deoxygenated Baltic Sea deeps indicates benthic flux and microbial transformation of chromophoric and fluorescent 
dissolved organic matter, Estuar. Coast. Shelf S., 163, 206-217, 2015.

Kratzer, C. R. and Brezonik, P. L.: A Carlson-type trophic state index for nitro gen in Florida Lakes, Water Res. Bull., 17, 713-715, 1981.

Kutser, T., Verpoorter, C., Paavel, B., and Tranvik, L. J.: Estimating lake carbon fractions from remote sensing data, Remote Sens. Environ., 157, 138-146, 2015.

Kwiatkowska, E. J., Ruddick, K., Ramon, D., Vanhellemont, Q., Brockmann, C., Lebreton, C., and Bonekamp, H. G.: Ocean colour opportunities from Meteosat Second and Third Generation geostationary platforms, Ocean Sci., 12, 703-713, doi:10.5194/os-12-703-2016, 2016.

Marker, A. F. H., Nusch, E. A., Rai, H., and Riemann, B.: The measurement of photosynthetic pigments in freshwaters and standardization of methods: Conclusions and recommendations, Arch. Hydrobiol. Beih. Ergebn. Limnol., 14, 91-106, 1980.

Miller, R. L., Belz, M., Del Castillo, C., and Trzaska, R.: Determining CDOM absorption spectra in diverse coastal environments using a multiple pathlength, liquid core waveguide system, Cont. Shelf Res., 22, 1301-1310, 2002.

Moran, M. A. and Hodson, R. E.: Support of bacterioplankton production by dissolved humic substances from three marine environments, Mar. Ecol.-Prog. Ser., 110, 241-247, 1994.

Morel, A. and Gentili, B.: The dissolved yellow substance and the shades of blue in the Mediterranean Sea, Biogeosciences, 6, 2625-2636, doi:10.5194/bg-6-2625-2009, 2009.

Morel, A. and Prieur, L.: Analysis of variations in ocean color, Limnol. Oceanogr., 22, 709-722, 1977.

Morel, A., Gentili, B., Claustre, H., Babin, M., Bricaud, A., Ras, J., and Tièche, F.: Optical properties of the "clearest" natural waters, Limnol. Oceanogr., 52, 217-229, 2007.

Morel, A., Claustre, H., and Gentili, B.: The most oligotrophic subtropical zones of the global ocean: similarities and differences in terms of chlorophyll and yellow substance, Biogeosciences, 7 , 3139-3151, doi:10.5194/bg-7-3139-2010, 2010.

Nelson, N. B. and Siegel, D. A.: Chromophoric DOM in the open ocean, in: Hansell, D. A. and Carlson, C. A., Biogeochemistry of Marine Dissolved Organic Matter, Academic Press, San Diego, CA, 547-578, 2002.

Organelli, E., Bricaud, A., Antoine, D., and Matsuoka, A.: Seasonal dynamics of light absorption by chromophoric dissolved organic matter (CDOM) in the NW Mediterranean Sea (BOUSSOLE site), Deep-Sea Res., 91, 72-85, 2014.

Palmer, S. C. J., Kutser, T., and Hunter, P. D.: Remote sensing of inland waters: Challenges, progress and future directions, Remote Sens. Environ., 157, 1-8, 2015.

Pope, R. M. and Fry, E. S.: Absorption spectrum (380-700 nm) of pure water. II Integrating cavity measurements, Appl. Optics, 36, 8710-8723, 1997.

Sathyendranath, S., Prieur, L., and Morel, A.: A three-component model of ocean colour and its application to remote sensing of phytoplankton pigments in coastal waters, Int. J. Remote Sens., 10, 1373-1394, 1989.

Siegel, D. A., Maritorena, S., Nelson, N. B., Behrenfeld, M. J., and McClain, C. R.: Colored dissolved organic matter and its influence on the satellite-based characterization of the ocean biosphere, Geophys. Res. Lett., 32, L20605, doi:10.1029/2005GL024310, 2005.
Stedmon, C. A. and Markager, S.: The optics of chromophoric dissolved organic matter (CDOM) in the Greenland Sea: An algorithm for differentiation between marine and terrestrially derived organic matter, Limnol. Oceanogr., 46, 2087-2093, 2001.

Stedmon, C. A., Markager, S., and Kaas, H.: Optical properties and signatures of chromophoric dissolved organic Matter (CDOM) in Danish coastal waters, Estuar. Coast. Shelf S., 51, 267-278, 2000.

Stramska, M., Stramski, D., Hapter, R., Kaczmarek, S., and Stoń, J.: Bio-optical relationships and ocean color algorithms for the north polar region of the Atlantic, J. Geophys. Res., 108, 3143, doi:10.1029/2001JC001195, 2003.

Strickland, J. D. H. and Parsons, T. R.: A practical handbook of seawater analyses. Fisheries Research Board of Canada, Ottawa, 1972.

Tassan, S.: Local algorithms using SeaWifs data for the retrieval of phytoplankton, pigments, suspended sediment, and yellow substance in coastal waters, App. Optics, 33, 2369-2378, 1994.

Tedetti, M., Charriére, B., Bricaud, A., Para, J., Raimbault, P., and Sempére, R.: Distribution of normalized water-leaving radiances at UV and visible wave bands in relation with chlorophyll a and colored detrital matter content in the southeast Pacific, J. Geophys. Res., 115, C02010, doi:10.1029/2009JC005289, 2010.

Toming, K., Kutser, T., Tuvikene, L., Viik, M., and Nõges, T.: Dissolved organic carbon and its potential predictors in eutrophic lakes, Water Res., 102, 32-40, 2016.

Vodacek, A., Blough, N. V., DeGrandpre, M. D., Peltzer, E. T., and Nelson, R. K.: Seasonal variation of CDOM and DOC in the Middle Atlantic Bight: terrestrial inputs and photooxidation, Limnol. Oceanogr., 42, 674-686, 1997.

Weishaar, J. L., Aiken, G. R., Bergamaschi, B. A., Fram, M. S., Fujii, R., and Mopper, K.: Evaluation of specific ultraviolet absorbance as an indicator of the chemical composition and reactivity of dissolved organic carbon, Environ. Sci. Technol., 37, 47024708, 2003.

Wetzel, R. G.: Limnology. Lake and River Ecosystems, Third Edn., Academic Press, San Diego, 1006, 2001.

Whitehead, R. F. and de Mora, S.: Marine Photochemistry and UV radiation, in: Issues in Environmental Science and Technology, edited by: Hester, R. E. and Harrison, R. M., Causes and Environmental Implications of Increased UV-B Radiation, Royal Society of Chemistry, 14, 37-60, 2000.

Wintermans, J. F. G. M and DeMots, A.: Spectrophotometric characteristics of chlorophylls $a$ and $b$ and their pheophytins in ethanol, Biochimica Biophysica Acta, 109, 448-453, 1965.

Woźniak, B. and Dera, J.: Light Absorption in Sea Water, Springer, New York, 2007.

Woźniak, S. B., Meler, J., Lednicka, B., Zdun, A., and Stoń-Egiert, J.: Inherent optical properties of suspended particulate matter in the southern Baltic Sea, Oceanologia, 53, 691-729, 2011.

Ylöstalo, P., Kallio K., and Seppälä J.: Absorption properties of inwater constituents and their variation among various lake types in the boreal region, Remote Sens. Environ., 148, 190-205, 2014. 